\title{
The Tale of Cotton Plant: From Wild Type to Domestication, Leading to Its Improvement by Genetic Transformation
}

\author{
Sabin Aslam ${ }^{1,2^{*}}$ (1), Sultan Habibullah Khan ${ }^{3}$, Aftab Ahmed ${ }^{3}$, Abhaya M. Dandekar ${ }^{2}$ \\ ${ }^{1}$ Center of Agricultural Biochemistry and Biotechnology, University of Agriculture, Faisalabad, Pakistan \\ ${ }^{2}$ Department of Plant Sciences, University of California, Davis, CA, USA \\ ${ }^{3}$ Center of Advanced Studies in Agriculture and Food Security, University of Agriculture, Faisalabad, Pakistan \\ Email: *sabinaslam@gmail.com, *sabaslam@ucdavis.edu, sultan@uaf.edu.pk, \\ aftab.ahmad@uaf.edu.pk,amdandekar@ucdavis.edu
}

How to cite this paper: Aslam, S., Khan, S.H., Ahmed, A. and Dandekar, A.M. (2020) The Tale of Cotton Plant: From Wild Type to Domestication, Leading to Its Improvement by Genetic Transformation. American Journal of Molecular Biology, 10, 91-127.

https://doi.org/10.4236/ajmb.2020.102008

Received: April 28, 2019

Accepted: February 14, 2020

Published: February 17, 2020

Copyright $\odot 2020$ by author(s) and Scientific Research Publishing Inc. This work is licensed under the Creative Commons Attribution International License (CC BY 4.0).

http://creativecommons.org/licenses/by/4.0/

\begin{abstract}
Cotton is considered as a major cash crop of the world. It earns huge foreign exchange by its valuable products; fiber, lint, cotton seed oil, hull and a lot more. Being an important fiber crop, it earns huge foreign exchange by contributing to textile and seed oil industry. This review summarizes cotton biology, its diversity and domestication, genome assembly, constraints in its production and methods to improve cotton plant to fulfill the need of textile and oil industry. But cotton is facing enormous biotic and abiotic stresses with insect pests being most prominent. Massive destruction caused by insects needs to be controlled for maintaining fruitful cotton crop production. Conventional breeding approaches are limited to improving single trait and integrate stable genes within plant genome in approximately 7 - 8 years. Improved biotechnological procedures have paved new pathways to target genes specifically and improve cotton germplasm in lesser time than conventional breeding.
\end{abstract}

\section{Keywords}

Cotton, Colored Cotton, Cotton Domestication, Genetic Diversity, Transformation

\section{Introduction}

Cotton is considered as the world's most important fiber producing crop. It not only supports textile industry by providing fiber but also supports oil industry by producing high quality oil. It is a major source of proteins $(30 \%-40 \%)$ to be fed 
to animals. Cotton is engaging approximately 350 million people around the globe for its production, ginning, transportation and storage. The world cotton market of $\sim 20$ billion annually is made possible by the uncommon ability of the cotton genus (Gossypium) to produce lint fibers that are single-celled, epidermal, five to six cm long, and seed-borne. The top three cotton-producing countries are China, India and the United States, followed by Pakistan, Brazil, Australia, Uzbekistan, Turkey, Turkmenistan, Burkina, Mali, Greece and Burma (Figure 1). China produces the most cotton, up to 6532 thousand metric tons annually (Figure 2). One hundred thousand Chinese farmers are engaged in cotton cultivation, where moderate rainfall favors production. About US \$73 billion in cotton cloth industry is earned by $\sim 7500$ textile companies in China. India is the world's second-largest cotton producer at 6423 thousand metric tons production each year. Massive cotton production in India is made possible by favorable environmental conditions in northern areas, with moderate temperatures of $25^{\circ} \mathrm{C}$ to $35^{\circ} \mathrm{C}$. Mechanized farming in India also contributes to increased cotton production [1].

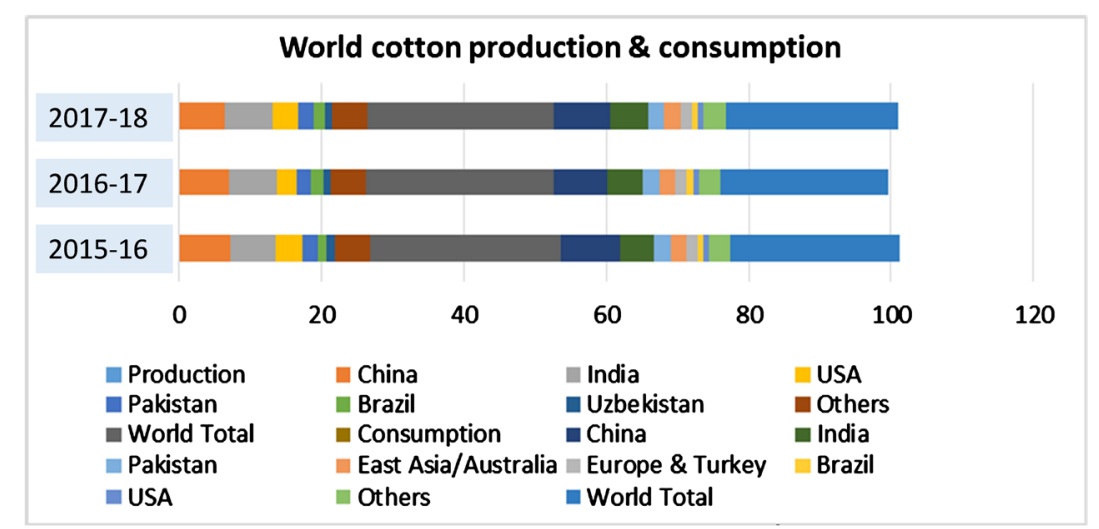

Figure 1. Production and consumption of world's major cotton growing countries (Economic survey of Pakistan 2018-19).

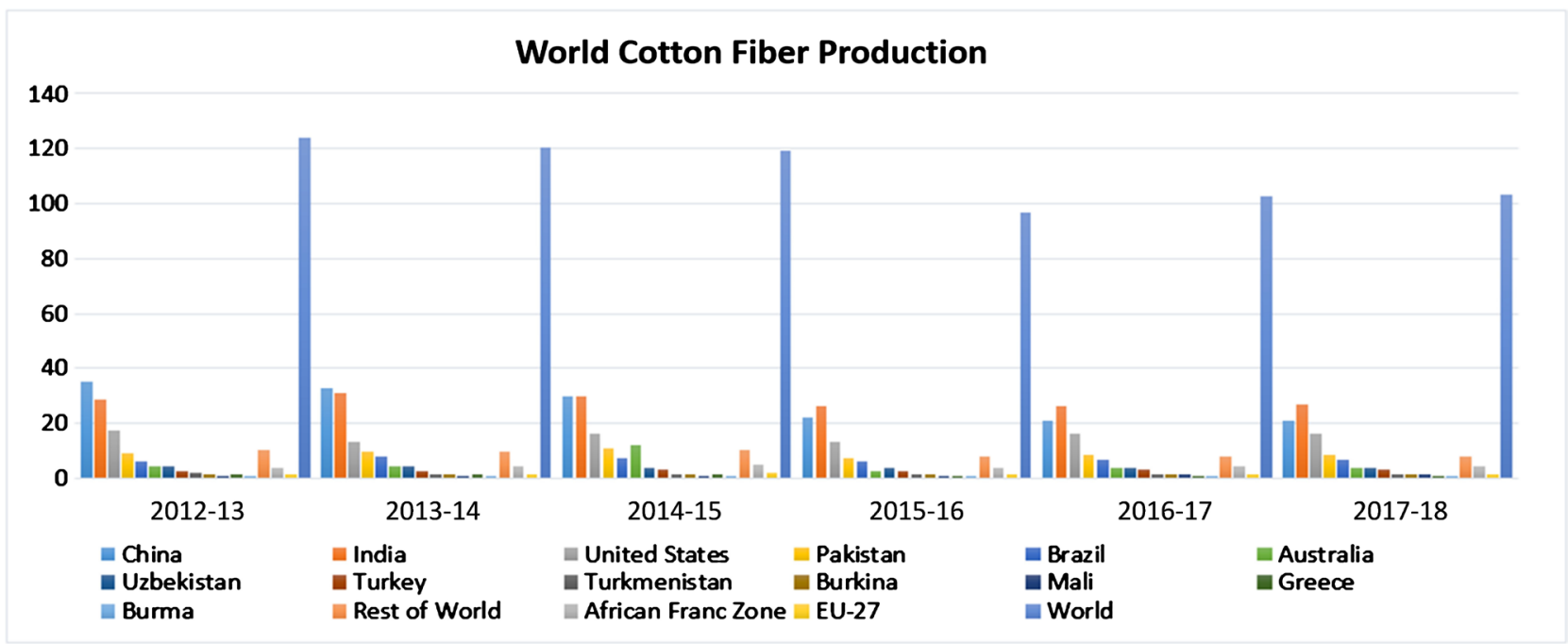

Figure 2. World cotton fiber production (Economic survey of Pakistan 2018-19). 
The United States of America is the third-largest cotton producer at 3553 thousand metric tons annually (Figure 2). Arizona, California, Florida, Mississippi and Texas are the major cotton-producing states. Cotton is cultivated on nearly $5 \mathrm{mha} / \mathrm{yr}$ in the United States, exceeding the area planted in all crops except wheat, maize and soybean [2]. The cotton fiber grown annually in the United States is worth $\sim 6$ billion dollars and the added value from cottonseed oil and meal is $\sim 500$ million dollars. Cotton fiber exports are worth four billion dollars annually. About 120 billion dollars is assessed for the business revenue of this crop [3]. The United States is progressively dependent on worldwide market for cotton to counteract the high demand for artificial fiber [2].

Pakistan is a prominent cotton producer and consumer and the economy depends profoundly on its cotton and textile industry (Table 1). The cotton and textile sectors contribute almost half the country's industrial base and cotton is the principal cash crop of Pakistan, providing critical income to country's households. The cotton-textile sectors comprise $11 \%$ of GDP and $60 \%$ of export earnings. Cotton is grown on $15 \%$ of the agricultural land from May to August, during monsoon season. It is also grown from February to April on a small scale. Pakistan stands at fourth position in world's cotton production behind China, India and the United States [4]. Pakistan stands third in exporting raw cotton, fourth in cotton consumption, and is the largest cotton yarn exporter [5]. However, the future of this essential part of the national economy is uncertain. This sector faces challenges from unbalanced prices and enhanced competition from worldwide liberalization of the multidimensional cotton and textile business. Therefore, Pakistan's economic circumstances are unstable [6]. As a cash crop, cotton represents a huge foreign exchange for Pakistan's economy, earning it the name "white gold of Pakistan". The textile industry earned $\$ 10.22$ billion in foreign exchange from July, 2016 to March, 2017. The cotton crop was grown on $2,961,000$ ha in $2017-18$, an increase of 5.5\% over the previous year. The 2017-18 cotton production was $11.8 \%$ increase over the previous year [7]. The shift from cotton production to rice and maize crops in some districts of Punjab contributed to the decreased acreage of cotton in Pakistan (Figure 3).

Table 1. Area, production and yield of cotton in Pakistan.

\begin{tabular}{ccccccc}
\hline & \multicolumn{2}{c}{ Area } & \multicolumn{2}{c}{ Production } & \multicolumn{2}{c}{ Yield } \\
\cline { 2 - 7 } Year & $(000$ Hectare $)$ & $\begin{array}{c}\text { \% age } \\
\text { Change }\end{array}$ & $(000$ Bales $)$ & $\begin{array}{c}\text { \% age } \\
\text { Change }\end{array}$ & (Kgs/Hec) & $\begin{array}{c}\text { \% age } \\
\text { Change }\end{array}$ \\
\hline $2013-14$ & 2689 & - & 11,460 & - & 725 & - \\
$2014-15$ & 2835 & 5.4 & 13,595 & 18.6 & 815 & 12.4 \\
$2015-16$ & 2879 & 1.6 & 13,031 & -4.1 & 769 & -5.6 \\
$2016-17$ & 2806 & -2.5 & 12,769 & -2 & 773 & 0.5 \\
$2017-18(\mathrm{P})$ & 2961 & 5.5 & 13,983 & 9.5 & 802 & 3.8 \\
\hline
\end{tabular}

Source: Pakistan Central Cotton Committee, M/O Textile indutry, 2018. E: Estimated, P: Projected. 


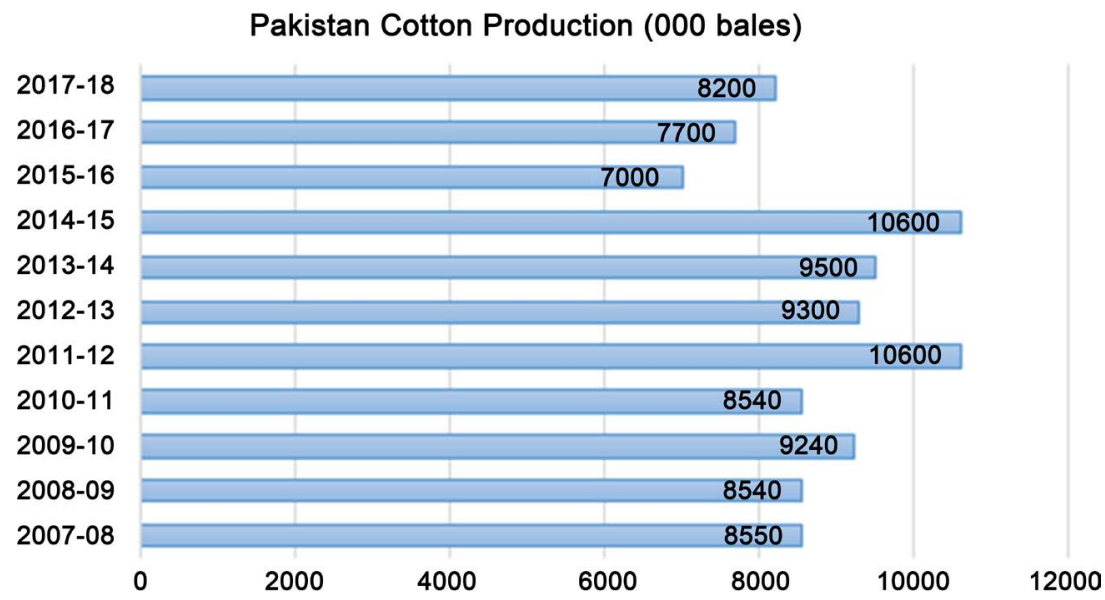

Figure 3. Cotton production in Pakistan (000 bales) (Economic survey of Pakistan 2018-19).

\section{Cotton Plant}

Cotton (Gossypium hirsutum L. and G. barbadense L.) is widely cultivated as a source of fiber. It is an annual, leafy shrub similar to Hibiscus that grows to $\sim 1.2$ $\mathrm{m}$. The plant has broad, heart-shaped leaves with thick veins and three to five lobes, a central stem with many branches, and roots that can reach $\sim 1.5 \mathrm{~m}$ deep. The cotton plant produces pink or light yellow flowers that, after pollination, give rise to a fruit called a boll. Each boll contains 27 to 45 seeds hidden within capsules surrounded by $28-\mathrm{mm}$ long 10,000 to 20,000 fibers. Cotton fiber is thin, hollow, and composed of cellulose surrounded by wax [8].

When a cotton seed is sown, it comes in contact with moist soil, imbibes water, and starts to germinate. Emergence occurs when cotyledons emerge from the soil surface and unfurl. Cotyledons grow faster in a warmer climate. Seedling establishment is best at a soil temperature of $16^{\circ} \mathrm{C}$ with at least three days of sunshine. Below this temperature, seedlings are susceptible to diseases like black root rot and Fusarium wilt. According to Dr. David Nehl (NSWDPI), a marked increase in seedling mortality was observed at soil temperatures under $15^{\circ} \mathrm{C}$ [9]. Cotton has an indeterminate growth habit: it produces fruit over a period of time, not simultaneously [10]. Development follows a specific pattern determined primarily by temperature variations and per-day degree calculations [10]. Under ideal conditions, seeds planted in warm, moist soil germinate and emerge in 5 - 10 days (Figure 4). The first two visible leaves are the cotyledons or seedling leaves, which in the presence of light begin photosynthesis. Conversion of sunlight to carbohydrates through photosynthesis provides food to the plant to help it develop normally [10]. Photosynthesis turns cotyledons into true leaves (leaves produced from the cotyledons) in two to four weeks, and they continue to feed the plant for the rest of its life. The plant develops continuously by adding leaves and increasing height. It produces small flower buds called squares in five to seven weeks. Bracts (striped leaf like parts) cover the small flower bud. After square development, the bud swells, pushes through the bracts, and opens into an attractive flower. Pollination occurs within three days, changing the 
flower's creamy white or yellow color to pinkish-red, then the flower wilts and falls off, uncovering a small, green, immature cotton boll. A cotton boll is a segmented fruit pod with thirty-two immature seeds from which the fibers originate. It enlarges to the size of a small fig as the fibers develop and thicken within the boll. At this stage, the mature cotton fibers are thickened with their chief component, the carbohydrate cellulose, also the major component of higher plants cell wall. Each plant may bear up to 100 bolls and the average boll contains $\sim 500,000$ cotton fibers [11]. About 140 days after planting, or nearly 45 days after the appearance of bolls, the cotton boll will start splitting naturally along its segments or carpels and begin to dry out, uncovering the underlying cotton segments called locks. Dried carpels are called the bur and when fully dried and fluffed, this bur holds locks of cotton firmly in place, ready for easy picking [10].

The genus of cotton is Gossypium, in the tribe Gossypieae of the mallow family, Malvaceae (Table 2). Cotton occurs naturally in arid to semiarid areas of subtropical and tropical regions in both the New and Old World. The genus Gossypium consists of $\sim 50$ species [12], making it the largest in the tribe Gossypioieae. The name of the genus is derived from the Arabic word goz, which means soft material [13]. The Gossypium genus originated $\sim 5$ to 10 million

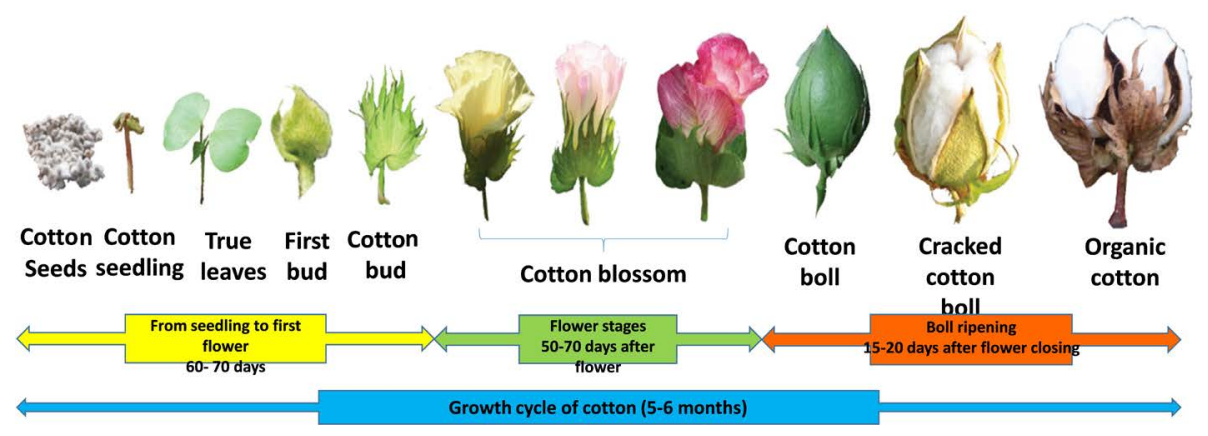

Figure 4. Life cycle of cotton (http://www.cottonsjourney.com/Storyofcotton/page3.asp).

Table 2. Cotton taxonomy.

\begin{tabular}{cc}
\hline Name & Cotton \\
Kingdom & Plantae \\
Unranked & Angiosperms \\
Unranked & Eudicots \\
Unranked & Rosids \\
Division & Mangoliophyta \\
Class & Mangoliopsida \\
Order & Malvales \\
Family & Malvaceae \\
Genus & Gossypium \\
\hline
\end{tabular}

Source: Tripathy et al., 2011. 
years ago [14]. The species included in the genus are extremely varied, both morphologically and physiologically, ranging from fire-borne, herbaceous perennials in Australia to tree species in Mexico [12].

The life cycle of the different cotton species varies, but the symmetry of fruit production remains almost the same. Insects, weather, and moisture can alter the ideal conditions for cotton growth drastically and it is the farmer's profession to regulate these conditions to adjust yield [9]. Perennial shrubs of cultivated cotton are most often grown as annual crops. Plants are $1-1.5 \mathrm{~m}$ high under modern cropping patterns, sometimes higher in conventional multi-cropping patterns. The leaves are wide and have $4-5$ lobes. The cottonseeds, located in the capsule-shaped boll, are enclosed by two types of fibers, which are detached from the seed by ginning. Firstly, the longer fibers, called staples, are detached and twisted together to produce yarn for making thread and weaving into high-quality fabric. Secondly, the linters are detached and woven into poor-quality fabric that contains the eponymous lint. Modern machines harvest cotton bolls without damaging the plant. Cotton production is boosted further by a favorable environment. Spinning machines and power looms were early, but enduring innovations to modern industry and help maintain consistent quality and quantity of cotton products [1].

The most common commercial species of cotton are G. hirsutum ( $>90 \%$ of world cotton production), G. barbadense (3\% - 4\%), G. arboreum and G. herbaceum (2\%) [15]. Most cotton varieties were derived through conventional breeding techniques like selection and hybridization. Current breeding programs seek to cross-breed traits such as insect/disease resistance and drought tolerance from wild cotton species into the major commercially cultivated species. Cotton fibers occur naturally as white, green, brown, and some blends of these shades [16]. Cotton is native to tropical and subtropical regions of the globe, mainly America, Australia, and Africa [8]. 17 native species of Gossypium are distant relatives of Australian flora [12]. Currently, 52 species of cotton are placed in the genus Gossypium. The Mayan civilization in Mexico first developed Gossypium hirsutum as a cultivated species [8].

Cotton is a popular natural fiber. Cultivated cotton is also an important oilseed crop and a major protein source for animal feed. This makes cotton a major player in the world economy and it is central to the industry, agriculture and employment of many subtropical and tropical regions in South America, Africa and Asia. Therefore, the genus Gossypium has long been the object of research [16]. All parts of the cotton plant are significant. Seeds are used for oil or as animal feed. Fiber is used in the textile industry to produce thread/fabric and remaining parts are mulched. Linters (small fibers removed from the seed after ginning) are a good source of cellulose. Linters are used to make products like cotton balls [8]. Among cotton products, lint (the fiber detached from the seed) is the major product; other products include textile and yarn products, automobile tire cord, plastic reinforcing and cordage. Cotton hulls are used for fuel, fer- 
tilizer, as packing material and the stalk fiber is used for pressed paper and cardboard [8]. Cottonseed oil is now considered as a chief byproduct of the cotton plant and has emerged as a distinct industry since its development in the latter half of the $19^{\text {th }}$ century. It is gradually becoming more important to cotton farmers as the natural cotton fiber meets competition from cheaper, stronger synthetic fibers cottonseed contains $\sim 20 \%$ oil. After detaching from the linters, seeds are shelled, pressed and crushed. The crude oil is extracted with solvents. Cottonseed oil is used as a cooking or salad oil, in margarine and shortening, and in a highly refined form, for cosmetics. It is used as a semidrying oil in paint. Candles, soap, detergents, oilcloth, artificial leather and many other commodities are manufactured from its less refined state [8]. Cotton is easily combined with linen to make velvet. It is less expensive than silk and can be printed more easily than wool. Its low market price makes it acceptable to the general public. The British midlands became a profitable center in the 1770s due to innovative techniques like the spinning jenny, water frame and spinning mule. British cotton export reached $15.6 \%$ from 1794 to 1796 and $42.3 \%$ from 1804 to 1806 [17].

Cotton is grown all around the world: 75 countries produce cotton for different purposes [18]. It is grown north and south of the equator to 45 to 35 degrees and comprises $\sim 31.7 \%$ of global agricultural production [19]. Cotton thrives in hot areas with low humidity and long periods of sunshine. Normally, its growing period starts in September/October and ends in March/April. Many insect species attack cotton and cause serious damage if not properly controlled. Major pests include aphids, mirids, whitefly, thrips and Helicoverpa caterpillar. Cotton is also affected by diseases, causing significant losses to industry. The most damaging diseases are Texas root rot, bacterial blight, blue disease, cotton leaf curl disease, and some strains of Verticillium and Fusarium wilt [20]. Abiotic factors (heat, drought, salinity, and waterlogging) affect cotton yield, especially during early stages of plant development [8].

Management improvements are an ongoing challenge as cotton producers face market realities. A producer's understanding and knowledge of the crop and ability to read the plant are critical to develop strategies to meet anticipated needs. Developing an integrated management approach to increase the efficiency of every production input and output is an essential element of a successful enterprise. Cotton producers will be expected to produce quality fiber and cotton products under increasing demands for environmental stewardship. Integrating management practices into an efficient system is the best approach to sustain the future of cotton production [21].

\section{Domestication of Cotton}

No one knows when cotton was first domesticated. Some 7000-years-old cotton boll fragments and wreckages of cloth have been found in Mexico, as this cotton was similar to that grown in America today. Cotton has been grown, spun and woven in the Indus valley of Pakistan since 3000 BC. At the same time, the inha- 
bitants of the Nile valley in Egypt were also wearing cotton clothes. Arabs brought cotton to Europe in 800 A.D. [19]. Columbus found cotton in the Bahamas during his exploration of America in 1492. After 1500, cotton was known worldwide. Florida started growing cotton in 1556 and Virginia, in 1607. Farmers were cultivating cotton in Virginia along the James River by 1616 . The first spinning of cotton by machine was done in England in 1730. Cotton ginning and the industrial revolution paved the way for today's world significance of cotton. A Massachusetts inhabitant, Eli Whitney, filed a patent on his cotton gin in 1793. Cotton ginning increased the quantity of cotton fiber that could be produced for textile industry [23]. Cotton was most likely domesticated some 7000 years ago. The foremost archeological evidence comes from the Neolithic occupation of Mehrgarh, dating to 6000 BC. G. arboreum and G. herbaceum are old-world cotton species. Both have genetic variation and perhaps differed well before domestication. Proper cultivation of $G$. arboreum started on the Indian subcontinent and spread to Asia and Africa. G. herbaceum was cultivated on the Arabian Peninsula and modern-day Syria. An African species was the ancestor of $G$. herbaceum, but the wild ancestor of G. arboreum is still unknown [22]. The trading empires of Europe and particularly the United Kingdom promoted cotton to global significance [19]. The most popular cotton fabrics in Europe were calico and chintz, which were imported to the United Kingdom in 1664 by the East India Company [23]. As Europeans became more interested in cleanliness and style, a fabric that was both easily washed and came in fascinating colors was in demand. The East India Company introduced cotton prints to the United Kingdom in 1690s [23].

Cotton is cultivated in temperate climates. The People's Republic of China, Uzbekistan, United States, and India produce the majority of the world's cotton crop. The leading states for cotton production are Arizona, Alabama, Arkansas, Georgia, California, Mississippi, Louisiana, Missouri, North Carolina, New Mexico, Florida, Oklahoma, Tennessee, South Carolina, Kansas, Texas, and Virginia. Other prominent cotton-growing countries include Brazil, Pakistan and Turkey [21]. The earliest evidence of cultivated G. hirsutum in Mesoamerica comes from excavations in the Tehuacan valley dating from 3400 to $2300 \mathrm{BC}$. Recent advances in cotton research compared seeds and bolls from cultivated and wild relatives of $G$. hirsutum, indicating that they are the same species, initially cultivated on the Yucatan Peninsula [12]. G. arboretum is a tropical plant, which has restricted its spread from southern Asia. It is grown in the Persian Gulf and some parts of North Africa. G. arboretum was recently found in Karatape, Uzbekistan [24]. G. herbacium is less familiar than G. arboretum. It was cultivated in the forests and plains of Africa. Its wild plants were taller, with small fruits and thick testa. No archeological remains of it have been recovered, but it has spread toward North Africa and the near East [24]. G. hirsutum and $G$. barbadense are considered New World cotton species [22]. G. hirsutum and $G$. barbadense were cultivated in Mexico and Peru, respectively. Some archeologists 
maintain that the most primitive form of cotton was domesticated from G. barbadense and was first cultivated in Mesoamerica. Others believe that G. hirsutum was solely domesticated in Mesoamerica [12]. Either way, cotton became an important cash crop and a valuable exchange element in Mesoamerica. Maya and Aztec merchants exchanged cotton articles and precious woven colored blankets. Aztec kings gave gifts of cotton items to their guests and army leaders [24]. Cotton remains from Ancon dating to $4200 \mathrm{BC}$ provide the earliest evidence for domestication of G. barbadense. By 1000 BC, Peruvian cotton bolls were still different from modern cultivated varieties of G. barbadense. The evidence of this form of cotton was found in some regions of Ecuador and on the middle coast of Peru [12].

Pakistan is among the pioneer cotton cultivation regions: the earliest known traces of cotton were found in Mehrgarh, near Quetta city: a copper bead with threads of cotton was found in a Neolithic burial site dated to $~ 6000$ BC. Metallurgical analysis of mineralized threads with light and scanning electron microscopy confirmed the presence of genus Gossypium [25]. Cotton threads have been recovered from archeological investigations of the Indus Valley civilization. Cultivation of cotton was extensive at the time of the Indus Valley civilization, covering areas of modern northwest India and eastern Pakistan [26]. Archeological indications of seeds from Mehrgarh have been dated back to 5000 BC. Cotton clothes were being used in Mohenjo-Daro and the Harappa Valley in 2500 BC. Cotton pollens were discovered at Balakot [27]. Evidence of cotton threads was found around mirror handles and copper razors dated to the mature $\mathrm{Ha}$ rappan period of $\sim 2500$ to 2000 BC. Other evidence of cotton was found in Balakot as pollen, in Banawali as seeds, and in Kanmer, Imlidhi Khurd, Kacchh, Sanghol and Gorakhpur as lint fibers [28].

\section{Colored Cotton}

Cotton varieties that produce colors other than off-white are important additions to modern marketable cultivated cotton. Green, red, and several shades of brown are the major natural colors of cotton varieties, which do not fade. The yield of colored cotton varieties is lower than commercially cultivated white cotton due to harvest constraints. Fiber is shorter and more fragile, but also softer than commercial white cotton. For better yield, specialized harvest technologies are required [29].

Sally Fox started postgraduate work on colored cotton in 1982. She first developed a long fiber of colored cotton and obtained patents for different shades of colored cotton including coyote brown, green, palo verde green and buffalo brown, under Fox Fiber [30]. In 1984, Raymond Bird worked on naturally colored cotton to improve its quality [31]. Colored cotton has excellent sun-protection properties. The color doesn't fade even after laundering and is environmentally friendly because it isn't dyed, which also saves the capital investment for fabric dyeing. Naturally colored cotton is more expensive ( $\$ 1.8$ to 5.0 per pound) than 
cultivated white cotton ( $\$ 0.75$ to 1.75 per pound) [30]. Colored cotton is grown in the United States, China, Russia and Brazil. China produces $\sim 61 \%$ of the world's colored cotton and exports to Western Europe, North America, Southeast Asia and Eastern Europe [29]. The fiber of colored cotton could help reduce the incidence of $\sim 50$ somatic and psychosomatic disorders in human beings [32]. Dyed cotton fabrics can trigger skin allergies and some dyes are carcinogenic, endangering textile workers [32]. Naturally colored cotton has shortcomings too. The fiber is short and is not harvested efficiently, causing great losses in yield. The color range is limited, sometimes not stable, and the fiber quality is low. Naturally colored cotton has very low market demand and fewer marketing facilities, but it could be a greener solution for cotton production and the textile industry. There may be increased demand for colored organic cotton, which might be a better price option for the cotton industry. Colored cotton can be a great source of wealth for rural families and woman empowerment [33]. Cotton plants have several key characteristics: okra-like leaves, nectriness, gossypol glands, reddish-brown stems and frago-bracts [8]. Existing colored cotton varieties can be improved through conventional breeding programs, biotechnology, or gene pool diversification. Understanding the mechanisms underlying pigment formation is critical for such efforts [8]. A comparison of the economics of colored and white cotton is given (Table 3 ).

\section{Cotton Genome}

Phylogenetic analysis places the genera Gossypoides and Kokia closest to the genus Gossypium (Figure 5). Genus Gossypium has 3 diploid progenitors. The $\mathrm{A}, \mathrm{B}, \mathrm{E}$ and $\mathrm{F}$ genomes constituted the African-Asian clade, the $\mathrm{D}$ genome formed the New World clade, and the C, G and K genomes gave rise to the Australian clade. Worldwide expansion led to differentiation in genome size based on morphology, ecology and chromosome pattern. Introgression and interspecific hybridization were the most common causes of speciation in Gossypium.

Table 3. Economics of growing colored cotton.

\begin{tabular}{ccc}
\hline & Colored cotton & White cotton \\
\hline Yield per acre & $600 \mathrm{Kg}$ & $1200 \mathrm{Kg}$ \\
Lint per acre (100 Kg seed cotton Yield $35 \mathrm{Kg}$ lint) & $210 \mathrm{Kg}$ & $420 \mathrm{Kg}$ \\
Yarn per acre (35 Kg lint = 30 Kg yarn) & $175 \mathrm{Kg}$ & $350 \mathrm{Kg}$ \\
Cloth per acre @ $30 \mathrm{Kg}=106$ meters & 169 Kg cloth or & $327 \mathrm{Kg}$ cloth or \\
No of shirts & 597 meters cloth & 1155 meters cloth \\
Price per shirt & 236 & 457 \\
Cost dying and processing & 1 Rs. $1000=236,000$ & 1 Rs. $500=228,500$ \\
\hline
\end{tabular}

Source: Economic survey of Pakistan, 2017. 


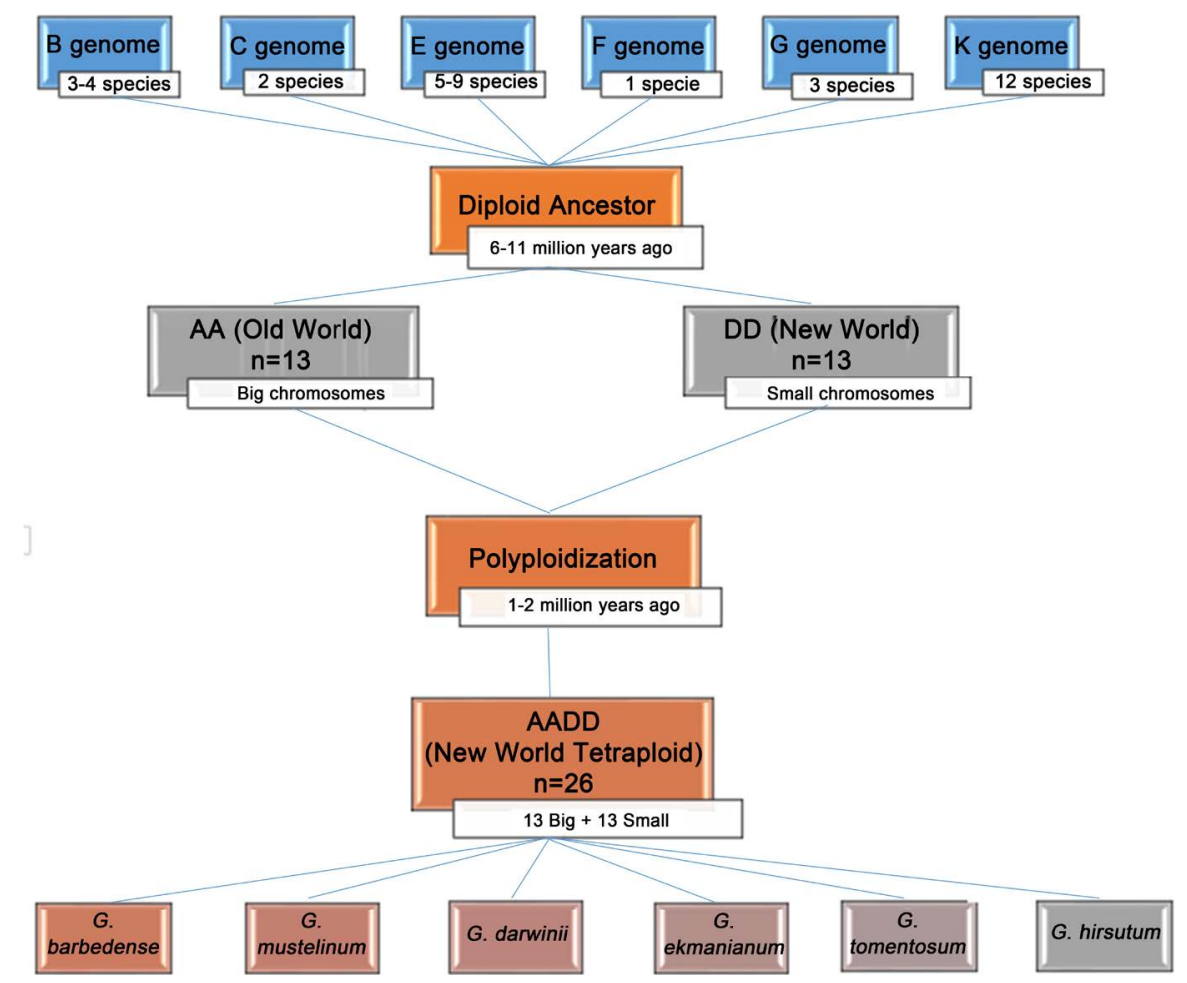

Figure 5. Phylogenetic relationship and evolution among the genus Gossypium.

Allopolyploidy occurred when American native A genome diploid cotton hybridized with a D genome female of immigrant New World G. raimondii [14]. Wild cotton plants are diploid, but a group of five tetraploid species is native to the Pacific Island and America, due to one hybridization incident $\sim 1.5$ to 2 million years ago. The tetraploid species are G. hirsutum, G. mustelinum, G. tomentosum, G. darwinii and G. barbadense [8].

A significant goal in cotton research is to study the genome of cultivated cotton and its relatives. Sequencing the cotton genome will help decipher important genetic components of the genus Gossypium. Gossypium is comprised of 52 species: 46 diploid species distributed in eight groups (A, B, C, D, E, F, G and K) and six tetraploid species (AD genome). Hybridization and polyploidization between the $\mathrm{A}$ and $\mathrm{D}$ diploid genomes resulted in the $\mathrm{AD}$ genome of tetraploid cotton. This polyploidization led to a remarkable combination of high yield potential and superior fiber quality compared to the A genome of G. arboretum, which has poor fiber quality, and the $\mathrm{D}$ genome of G. raimondii, which does not produce a spinable fiber [34]. Genomic research on cotton started as an analysis of the genetic diversity of diploid and allotetraploid species using SSR markers in A- and D-genome species of Gossypium (Guo et al., 2003). High polymorphism among Gossypium species with A- or D-genomes was found and the molecular cluster was consistent with previously-defined Gossypium taxonomy (Fryxell, 1965). G. gossypioides, with a D-genome, was least similar to other D-genome diploid species, emphasizing the significance of G. gossypioides as the original D-genome cotton specie. To understand allopolyploidization in Gossypium, two 
allotetraploid cotton species were studied, but allotetraploid cotton species were inappropriate for studying the evolution of the $\mathrm{A}$ and $\mathrm{D}$ genomes [35]. The formation of Gossypium polyploids and their role in the evolution of new species was examined using a polyploid of $G$. barbedense with an AD genome: 83 non-cross hybridizing clones with discrete replications consisting of $\sim 24 \%$ of nuclear DNA [36]. The A-genome encompasses 77\% of nuclear DNA. FISH analysis depicted the spread of some A-genome repeats to D-genome chromosomes in tetraploid cotton. Only G. gossypioides had adequate levels of A-genome repeat sequences, including $\mathrm{D}$-genome replications. The spread of discrete repeats in polyploids gave contribution of diploid progenitors. Most DNA sequences in the clones did not match known DNA sequences: only four were linked to transposable elements, some had internal repeats and $\sim 12$ could hybridize to mRNAs. A new breakthrough in the evolution of polploidy was observed using cytogenetic and phylogenetic analysis of discrete DNA repeats [36]. Two types of genomes are present in G. hirsutum: DT and AT genomes [37]. Diploid ancestors with A and D genomes gave rise to these genomes in G. hirsutum during allopolyploidization. The A1, A2 and D5 genomes were re-sequenced in the diploid cotton species G. herbacium, G. arboreum and G. raimondii, respectively. Twenty-four million single nucleotide polymorphisms between $\mathrm{A}$ and $\mathrm{D}$ diploid genomes were analyzed for multiple lines of each diploid species using deep re-sequencing. A vigorous catalog of SNPs conserved between A and D genomes was found at all polymorphic loci. This catalog could aid mapping studies of all diploid and allopolyploid races of Gossypium. Putative duplications and deletions in the $\mathrm{A}$ genome relative to the $\mathrm{D}$ genome sequence were mapped precisely. About 50\% deletions were observed in $\sim 978$ genes, including 25,400 deleted regions, $\sim 1472$ conversion events of homologous chromosomes and overlapping for 113 genes [37].

Public sector research produced a superior sequence of the draft genome from reads created by all available sources, Sanger reads of bacterial artificial colonies, cosmids and plasmids, and 454 reads. These advanced reads will be influential in ordering an initial draft D-genome [38]. About 50× of the D-genome of G. raimondii was covered through illumina sequencing by Monsanto and Illumina in 2010 [39]. The raw reads were donated to the community. The assemblage of the $\mathrm{AD}$-genomes of cultivated cotton varieties requires assembling the $\mathrm{D}$-genome from raw material: a formidable task [13]. Gene Trek and BAC tagging techniques were used to identify the organization and configuration of the genome of allotetraploid cotton [40]. Analysis of BAC sequences showed 70,000 genes with replicas in homeologous regions of A and D-subgenomes. Uneven gene distribution was observed, with both gene-rich and gene-poor sections. Among BACs, $21 \%$ lacked genes. Other gene islands averaged $\sim 1.5$ genes/island, with $\mathrm{BAC}$ gene density ranging from 0 to $33.2 / 100 \mathrm{~kb}$. In D-genome, 125 polymorphic loci were marked out of 166 loci. Thirty-seven BACs, 12 from the A-genome and 25 from the D-genome, were attached to their analogous subgenomes, suggest- 
ing that introns play no role in altering the size of subgenomes in cotton species [40]. The importance of polyploidy as a key factor for increased quality and fiber productivity was emphasized [41]. A five- to six-fold increase in ploidy level occurred in cotton $\sim 60$ million years ago and allopolyploidy occurred one to two million years ago. The evolution of embryonic fiber before allopolyploidy is confirmed by the occurrence of spinnable and non-spinnable fibers in the A and F-subgenomic species G. herbacium and G. longicalyx, respectively, and in the $\mathrm{D}$-genome of $G$. raimnondii. Several non-reciprocal interactions between genomes contribute to innovative properties in the G. hirsutum AD genome. The novel properties of $G$. hirsutum were obtained by recombining D- and A-genome alleles [41]. A draft genome was sequenced for $G$. raimondii, the descendant of the significant D-subgenome species G. hirsutum and G. barbadense. Thirteen chromosomes of $G$ raimondii contain $\sim 73 \%$ of the assembled sequences. Transcriptome analysis confirmed 40,976 protein-coding genes in the genome. Thirteen to twenty million years ago, hexaploidization and whole-genome duplication events occurred in eudicots of various cotton species. The G. raimondii genome had $\sim 2355$ syntenic blocks and $\sim 40 \%$ paralogues genes in more than one block, suggesting the significance of chromosomal rearrangements during evolution of cotton species. Phylogenetic analysis found the cadinene synthase (CDN) gene family, for the synthesis of gossypol glands, only in species of cotton and Theobroma cacao [38]. A whole genome marker (WGMM) of cotton was based on the sequenced D-genome of G. raimondii [42]. A WGMM of 48,959 loci was created for cotton [43], comparable to the rice and brassica genetic maps of 15,759 SNPs and 13,551 sequence-related amplified polymorphisms, respectively [44] and [45]. This cotton WGMM aided targeted research for gene cloning, association mapping of cotton and other related genes, and genome-wide studies. The WGMM is a significant resource for understanding QTLs for cotton fiber development, association mapping, pest resistance gene analogue clusters, gene structure, and variation [42].

The genome of allotetraploid cotton (AADD; $2 \mathrm{n}=52$ ) makes genetic, genomic and functional analysis difficult. The genome of $G$. arboretum (AA; $2 \mathrm{n}=26)$, an assumed donor of the A-subgenome, has been assembled [46]. Paired-end sequencing used $193.6 \mathrm{~Gb}$ of fresh sequencing, covering the genome 112.6 times. Subsequently, $90.4 \%$ of the sequenced array on 13 pseudo chromosomes and $68.5 \%$ of the genome made up of repetitive DNA sequences was aligned. Up to 41,330 gene-coding sequences in G. arboreum were defined. G. raimondii and $G$. arboreum shared two whole-genome doublings before speciation. The differences in genome sizes stem from the addition of repeats at terminal regions five million years ago [47]. An A-genome sequencing project for Gossypium was initiated in 2007 [15]. The goal was to sequence the entire genome of commercially cultivated allotetraploid cotton species. "Allotetraploid" indicates that these cotton genomes consist of two diverse subgenomes, the At and Dt (the " $t$ " denotes tetraploid and differentiates from the A and D-genomes of related diploid spe- 
cies). The D-genome of the allotetraploid relative of cotton, G. raimondii, was sequenced first. G. raimondii is a wild cotton species of South America (Peru, Ecuador) and its genome is smaller due to less replicative DNA (primarily retrotransposons). The $G$. raimondii genome has a 3 times fewer bases than tetraploid $\mathrm{AD}$ cotton due to the sole presence of each chromosome. The "Old-World" A-genome cotton species $G$. arboretum, cultivated in India, was decided to be sequenced next. The genome of G. arboreum is about twice the size of G. raimondii. Once both genomes are completely sequenced, the genomes of cultivated tetraploid cotton varieties can be sequenced. This strategy is necessary because if the tetraploid genome were sequenced without model diploid genomes, the euchromatic DNA sequences of the AD genomes would co-assemble and the repetitive elements would assemble independently into $\mathrm{A}$ and $\mathrm{D}$ sequences, respectively. The AD sequences can only be untangled by comparison with their diploid counterparts [46].

The G. arboreum genome is $1746 \mathrm{Mb} / 1 \mathrm{C}$, roughly double the $885 \mathrm{Mb} / 1 \mathrm{C}$ of G. raimondii [48]. Two groups independently sequenced the genome of $G$. raimondii [38] and [41]. The G. arboreum A2-genome has also been sequenced and assembled [46]. A draft genome of cultivated $G$. hirsutum was published by two independent groups [47] and [49]. Gossypium hirsutum, Gossypium raimondi and Gossypium arboreum has been sequenced (Table 4).

\section{Genetic Diversity of Cotton}

The sum of all genetic characters in a species' genetic makeup constitutes its genetic diversity. Genetic diversity is different from the genetic variability, or differences among genetic characters. Species diversify as they adapt to a changing environment, when individuals with the best-suited alleles produce more offspring.

Table 4. Sequenced genome of cotton.

\begin{tabular}{|c|c|c|c|c|c|c|c|c|c|c|c|}
\hline $\begin{array}{l}\text { Cotton } \\
\text { Species }\end{array}$ & $\begin{array}{l}\text { Genom } \\
\text { e } \\
\text { Code }\end{array}$ & $\begin{array}{l}\text { Estimated } \\
\text { genome } \\
\text { Size }\end{array}$ & $\begin{array}{l}\text { Sequenced } \\
\text { Genome } \\
\text { Size }\end{array}$ & Materials & $\begin{array}{l}\text { Sequencing } \\
\text { Company }\end{array}$ & $\begin{array}{l}\text { Contig } \\
\text { Scaffold } \\
\text { (Kb) }\end{array}$ & $\begin{array}{c}\text { \# of } \\
\text { Coding } \\
\text { Genes }\end{array}$ & $\begin{array}{l}\text { Micro } \\
\text { RNAs }\end{array}$ & $\begin{array}{l}\text { \%Repeat } \\
\text { Sequences }\end{array}$ & $\begin{array}{c}\text { NCBI } \\
\text { Accession } \\
\#\end{array}$ & Reference \\
\hline G. raimondi & D5 & $880 \mathrm{Mb}$ & $775.2 \mathrm{Mb}$ & D5-3 & $\begin{array}{l}\text { Illumina HiSeq } \\
2000\end{array}$ & $2284 \mathrm{~Kb}$ & 40,976 & 348 & 57 & PRJNA82769 & $\begin{array}{l}\text { Wang } \\
\text { et al., } 2012\end{array}$ \\
\hline G. raimondi & D5 & $880 \mathrm{Mb}$ & $737.8 \mathrm{Mb}$ & $\underset{\text { raimondi }}{G}$ & $\begin{array}{c}\text { Applied } \\
\text { Biosystems } \\
3730 \text { XL, Roche } \\
454 \text { XLR \& } \\
\text { Illumina GA llx }\end{array}$ & $18.8 \mathrm{Mb}$ & 37,505 & 364 & 61 & PRJNA171262 & $\begin{array}{l}\text { Paterson } \\
\text { et al., } 2012\end{array}$ \\
\hline G. arboreum & A2 & $\begin{array}{c}1677-1746 \\
\mathrm{Mb}\end{array}$ & $1694 \mathrm{Mb}$ & SXY1 & $\begin{array}{l}\text { Illumina HiSeq } \\
2000\end{array}$ & $665.8 \mathrm{~Kb}$ & 41,330 & 431 & 68.5 & SRA150181 & $\begin{array}{l}\text { Li et al., } \\
2014\end{array}$ \\
\hline G. hirsutum & $\mathrm{AD}$ & $\begin{array}{c}2347-2489 \\
\mathrm{Mb}\end{array}$ & $2173 \mathrm{Mb}$ & TM-1 & $\begin{array}{c}\text { Illumina Hiseq } \\
2000\end{array}$ & $764 \mathrm{~Kb}$ & 76,913 & 301 & 67.2 & PRJNA259930 & $\begin{array}{l}\text { Li et al., } \\
2015\end{array}$ \\
\hline G. hirsutum & $\mathrm{AD}$ & $\begin{array}{c}2327-2489 \\
\mathrm{Mb}\end{array}$ & $2400 \mathrm{Mb}$ & TM-1 & $\begin{array}{c}\text { Illumina HiSeq } \\
2000 \text { Sanger } \\
\text { Sequencing }\end{array}$ & $1600 \mathrm{~Kb}$ & 70,478 & 602 & 64.8 & PRJNA248163 & $\begin{array}{l}\text { Zhang } \\
\text { et al., } 2015\end{array}$ \\
\hline
\end{tabular}

Source: http://www.cicr.org.in/. 
Gossypium hirsutum, a cultivated upland cotton with an (AD) $)_{1}$ genome and extra-long staple length, and Gossypium barbedense, with an $(\mathrm{AD})_{2}$ genome, evolved through whole-genome duplication as neoployploids with different genomes. Gossypium barbedense produces the strongest fiber or any plant, with a long staple and pure cellulose composition [50].

Genetic diversity effects in inbreds of cotton were observed in Xiangzamian 2 (XZM2) hybrid cotton in China, which was a cross between Zhongmiansuo I2 and 8891. One hundred eighty recombinant lines were produced after nine generations [53]. Ten agronomic traits in a population were studied over two years. SSR markers determined the genetic map of the XZM2 hybrid and single- and double-locus studies used QTLs. The genetic base of cotton agronomic traits is influenced by additive and epistatic effects of QTLs [53]. Fiber quality traits were studied using association mapping and genetic diversity [51]. Linkage disequilibrium served as an alternative approach to use the genetic diversity of Gossypium species. Genome-wide linkage disequilibrium was used to examine fiber quality characters. An $11 \%$ to $12 \%$ significant linkage disequilibrium was designated by SSR markers among 208 landraces and 77 cultivars with a significant similarity in population structure. This demonstrated the potential of cotton cultivars for stratification and population structure using association mapping [52].

Cotton breeding programs rely on relatedness of varieties and the molecular diversity of germplasm. The distance between microsatellite loci in 53 cotton varieties was determined [53]. Characterization with 31 SSR primer pairs indicated 66 alleles, with an average 2.13 alleles per locus. The microsatellite markers distinguished 52 unique genotypes among the 53 cultivars [53]. Forty-three types of Chinese upland cotton germplasm based on parent type, breeding time and agroecological zone were studied, yielding $80 \%$ polymorphism in 130 genes with 36 SSRs [54]. The germplasm diversity of Chinese accessions decreased at the second and third level of the base germplasm, showing limited genetic variability. Genetic diversity in introduced varieties was greater than in domestic varieties [54]. In the United States, 378 Gossypium hirsutum and three Gossypium barbadense accessions were characterized using 120 gene-specific microsatellites to identify population structure and genetic diversity of tetraploid cotton [55]. One hundred forty-one SSR loci were identified with 546 alleles, of which 22\% were unique. Population analysis by STRUCTURE distinguished five groups as belonging to the southwest, mid-south, southeastern and western cotton belts of United States; the three Gossypium barbadense lines formed a distinct group. Low genetic diversity was observed among upland cotton genotypes at a 0.195 mean genetic distance between Gossypium hirsutum lines. Population structure and phylogenetic analysis results were consistent with pedigree evidence [55].

The genetic diversity of 40 releases from a Pakistani cotton breeding program from 1914 to 2005 was evaluated [33]. The genetic diversity of Pakistani cotton germplasm was relatively low over time in the previous releases, showing conservation of elite cotton genotypes for use in future breeding programs [33]. The 
genomic diversity of 20 cotton cultivars was examined using 31 microsatellite markers. Only two genotypes, K-68/9 and MNH-93, had the maximum significant similarity [56].

\section{Constraints in Cotton Production}

\subsection{Insect Pests}

A wide range of insect pests attack cotton: The most damaging insects include ash weevils, cotton aphids, cotton stem weevil, dusky cotton bug, fruit borer, leaf hopper, leaf roller, mealy bug, pink bollworm, spotted boll worm, shoot weevil, red cotton bug, stem borer, thrips, tobacco cutworm and white fly (Table 5). Integrated pest management is a critical step to boost cotton production. Formally, the most devastating cotton pest in North America was cotton boll weevil. This pest was completely eradicated by the efforts of the Boll Weevil Eradication Program (BWEP) of the United States Department of Agriculture. Synthetic pesticide use was reduced with the introduction of Bt cotton, genetically modified against cotton bollworm and pink bollworm.

\subsection{Diseases}

Cotton production is greatly affected by diseases causing yield loss and poor-quality seed and fiber. Cotton is affected by bacterial, viral, fungal, nematodal, phytoplasmal and spiroplasmal diseases (Table 6).

Cotton leaf curl disease (CLCuD) is the most devastating disease of cotton in Asia, Africa and United States. A complex of virus and DNA $\beta$-satellite molecule causes CLCuD. Nine virus species in the genus Begomovirus and DNA beta and alpha satellites are linked to cotton leaf curl disease in these regions, particularly in India and Pakistan. The first evidence of CLCuD on Gossypium hirsutum plants was reported in 1967 in the Multan district of Pakistan. It spread to all major growing areas in Pakistan and India. Due to low host resistance in existing cultivated cotton varieties, two epidemics have occurred in the past two decades. In the early 1990s, an outbreak of CLCuD devastated Pakistan's cotton industry, causing 30\% to 35\% estimated yield loss. The economic loss of Pakistan in 1992 and 1997 reached 5 billion dollars [57] and cotton production reduced to $\sim 70 \%$ by 1998 in some Indian states of Punjab [58]. A 52.7\% and 54.2\% decrease in boll number and cotton boll weight was observed, respectively. Yield losses were up to $50 \%$ in resistant varieties and $85 \%$ to $90 \%$ in susceptible varieties [59]. Cotton production rebounded in the mid-1990s, when resistant cotton varieties were introduced into the Indian subcontinent [60]. Resistance broke in 2001-2002, when new strains of CLCuV emerged that attacked previously resistant varieties, including CP-15/2, Cedex and LRA-5166 [20]. Even China, far from $\mathrm{CLCuD}$ hotspots of the Indian subcontinent, reported some symptoms of this disease, raising concerns that the disease could spread far from its point of origin [61]. Molecular biologists struggled to understand the biology of CLCuV to combat this disease [62]. These efforts are hindered by the complicated nature 
Table 5. Cotton insects.

\begin{tabular}{|c|c|c|c|}
\hline Insect & Scientific name & Symptoms of damage & Management \\
\hline Ash weevlis & $\begin{array}{l}\text { Mylloecerus } \\
\text { undecimpustulatus }\end{array}$ & $\begin{array}{l}\text { - Nicked leaf margins } \\
\text { - Patched leaf wilting } \\
\text { - Weak roots grip } \\
\text { - Destroyed roots }\end{array}$ & $\begin{array}{l}\text { Cultural: } \\
\text { - Eradication and destruction of affected plant parts } \\
\text { Chemical: } \\
\text { - Insecticidal spray (Quinalphos or chlorpyriphos) }\end{array}$ \\
\hline Cotton aphid & Aphis gossypii & $\begin{array}{l}\text { - Leaf crunkles } \\
\text { - Stunted plant growth } \\
\text { - Leaf blight } \\
\text { - Dark plant appearance due to black mould } \\
\text { - Tender leaves \& shoots }\end{array}$ & $\begin{array}{l}\text { Chemical: } \\
\text { - Insecticidal sprays (Methyl demeton, Acetamiprid, } \\
\text { Carbosulfan, Fipronil, Imidacloprid or Malathion) }\end{array}$ \\
\hline $\begin{array}{l}\text { Cotton stem } \\
\text { weevil }\end{array}$ & Pempheres affinis & $\begin{array}{l}\text { - Stem swelling } \\
\text { - Young plant death } \\
\text { - Nodal breakage during wind } \\
\text { - Lack of vigor \& strength in mature plant }\end{array}$ & $\begin{array}{l}\text { Cultural: } \\
\text { - FYM application } \\
\text { - } 10 \%-20 \% \text { Infestation } \\
\text { Chemical: } \\
\text { - Seed treatment (Chlorpyriphos) } \\
\text { - Insecticidal spray (Carbaryl or carbofuran) }\end{array}$ \\
\hline $\begin{array}{l}\text { Dusky cotton } \\
\text { bug }\end{array}$ & Oxycarenuchyalinipennis & $\begin{array}{l}\text { - Sap sucking } \\
\text { - Lint blackening } \\
\text { - Shrunken seeds } \\
\text { - Seeds discoloration }\end{array}$ & $\begin{array}{l}\text { Chemical: } \\
\text { - Insecticidal Phosphamidon spray }\end{array}$ \\
\hline Fruit borer & Helicoverpa armigera & $\begin{array}{l}\text { - Boll feeding } \\
\text { - Regular circular bore holes } \\
\text { - } 30 \text { - } 40 \text { bolls damaged by a single larva } \\
\text { - Granular faecal pellets outside bore holes }\end{array}$ & $\begin{array}{l}\text { Cultural: } \\
\text { - Synchronized sowing with short duration varieties } \\
\text { - Avoid continuous cropping } \\
\text { - Avoid monocropping } \\
\text { - Destruction \& removal of crop residues } \\
\text { - Water management for larval harborage } \\
\text { - Avoid moth multiplication with optimized use of } \\
\text { nitrogenous fertilizers } \\
\text { Biological: } \\
\text { - Nuclear Polyhedrosis virus } \\
\text { - Bacillus thuringiensis } \\
\text { - Beauveriabassina } \\
\text { - Natural predators \& parasitoids } \\
\text { - Egg parasitoid, Trichogramma spp. } \\
\text { Chemical: } \\
\text { - At early stage of square formation (Acephate, } \\
\text { - carbaryl, Diflubenzuron, Lufenuron or Pyridalyl) } \\
\text { During boll formation and maturity (Quinalphos, } \\
\text { Carbaryl or Pyraclofos) }\end{array}$ \\
\hline Leaf hopper & Amrasca devastans & $\begin{array}{l}\text { - Leaf yellowing } \\
\text { - Leaf curling } \\
\text { - Bronze colored leaf hopper burn } \\
\text { - Crumbled leaf margins } \\
\text { - Leaf shedding } \\
\text { - Complete crop destruction }\end{array}$ & $\begin{array}{l}\text { Chemical: } \\
\text { - Insecticidal spray (Carbofuran, Imidacloprid, } \\
\text { Buprofezin, Fipronil, Phosalone or Thiacloprid) } \\
\text { - Neem oil treatment }\end{array}$ \\
\hline Leaf roller & Sylepta derogate & $\begin{array}{l}\text { - Leaf rolling } \\
\text { - Biten marginal leaf portions } \\
\text { - Crop defoliation }\end{array}$ & $\begin{array}{l}\text { Cultural: } \\
\text { - Picking \& destroying of broken \& shedded leaves } \\
\text { - Manual picking \& destruction of young caterpillers } \\
\text { Chemical: } \\
\text { - Insecticidal sprays (Chlorpyriphos or dichlorovos) }\end{array}$ \\
\hline Meally bug & Phenacoccus species & $\begin{array}{l}\text { - A mat of mealy bugs under leaf surface } \\
\text { - Thick wax emission } \\
\text { - Honeydew secretion } \\
\text { - Development of black mould } \\
\text { - Black plant appearance } \\
\text { - Diminished fruiting }\end{array}$ & $\begin{array}{l}\text { Cultural: } \\
\text { - Weeds eradication } \\
\text { - Parasitoids } \\
\text { Chemical: } \\
\text { - Spray with Profenophos } \\
\text { - Treatment with neem oil }\end{array}$ \\
\hline
\end{tabular}


Continued

\begin{tabular}{|c|c|c|c|}
\hline $\begin{array}{l}\text { Pink boll } \\
\text { worm }\end{array}$ & Pectinophora gossypiella & $\begin{array}{l}\text { - Larval excreta at bore hole point } \\
\text { - Rossette flowering } \\
\text { - Double seeds } \\
\text { - Early boll shedding } \\
\text { - Fade colored lint } \\
\text { - Hollow seeds }\end{array}$ & $\begin{array}{l}\text { Cultural: } \\
\text { - Timely crop harvesting } \\
\text { - Rapid crop remains destruction } \\
\text { - Timed irrigation } \\
\text { - Ploughing \& mulching } \\
\text { - Crop rotation with alfalfa } \\
\text { Chemical: } \\
\text { - Bolgard II } \\
\text { - Spinosad formulation sprays }\end{array}$ \\
\hline $\begin{array}{l}\text { Red cotton } \\
\text { bug }\end{array}$ & Dysdercus cingulatusi & $\begin{array}{l}\text { - Decayed bolls } \\
\text { - Red colored lint } \\
\text { - Water soaked bolls } \\
\text { - Boll browning } \\
\text { - Premature boll shedding }\end{array}$ & $\begin{array}{l}\text { Cultural: } \\
\text { - Field ploughing } \\
\text { Chemical: } \\
\text { - Insecticidal phosphamidon spray }\end{array}$ \\
\hline Shoot weevil & Alcidodes affaber & $\begin{array}{l}\text { - Shoot galls } \\
\text { - High marginal bore holes }\end{array}$ & $\begin{array}{l}\text { Cultural: } \\
\text { - FYM application } \\
\text { Chemical: } \\
\text { - Soil treatment with Carbofuran }\end{array}$ \\
\hline $\begin{array}{l}\text { Spotted } \\
\text { bollworm }\end{array}$ & Earias vittela & $\begin{array}{l}\text { - Terminal shoots wilting } \\
\text { - Bolls \& squares shedding } \\
\text { - Bracts flaring up at boll formation stage } \\
\text { - Holes \& rotting of bolls }\end{array}$ & $\begin{array}{l}\text { Chemical: } \\
\text { - Insecticides (Carbaryl, Chlorantraniliprole, } \\
\text { Indoxacarb, Phosalone or Triazophos) } \\
\text { Biological: } \\
\text { - Bacillus thuringiensis }\end{array}$ \\
\hline Stem borer & Sphennoptera gossypii & $\begin{array}{l}\text { - Drooped leaves } \\
\text { - Wilting }\end{array}$ & $\begin{array}{l}\text { Cultural } \\
\text { - Soil treatment with Carbofuran } \\
\text { - Application of FYM }\end{array}$ \\
\hline Thrips & Thrips tabaci & $\begin{array}{l}\text { - Leaf epidermal removal } \\
\text { - Leaf wrinkling } \\
\text { - Destroyed bud edges } \\
\text { - Shiny grey under leaf surface }\end{array}$ & $\begin{array}{l}\text { Chemical: } \\
\text { - Imidacloprid seed treatment } \\
\text { - Insectcidal sprays (Imidacloprid, Methyl demeton or } \\
\text { Dimethoate) }\end{array}$ \\
\hline $\begin{array}{l}\text { Tobacco } \\
\text { cutworm }\end{array}$ & Spodoptera litura & $\begin{array}{l}\text { - Leaf veins skeleton } \\
\text { - Scrapped leaf epidermal layer } \\
\text { - Bare plants without leaves or bolls } \\
\text { - Small holes on leaves }\end{array}$ & $\begin{array}{l}\text { Cultural: } \\
\text { - Light traps } \\
\text { - Sex pheromone trap } \\
\text { - Castor bordering } \\
\text { - Destruction of larval clusters } \\
\text { - Manual collection of shed plant parts } \\
\text { - Destruction of young caterpillars } \\
\text { Chemical: } \\
\text { - Insecticidal spray (Chlorpyriphos, } \\
\text { Chlorantraniliprole, Diflubenzuron or Nuclear } \\
\text { - Polyhedrosis virus) } \\
\text { Poison bait rice bran pellets }\end{array}$ \\
\hline White fly & Bemicia tabaci & $\begin{array}{l}\text { - Leaf petiole \& veins chlorosis } \\
\text { - Premature complete leaf shedding } \\
\text { - Mould spreading } \\
\text { - Buds \& bolls shedding } \\
\text { - Lesser boll opening } \\
\text { - Major vector of Cotton leaf curl virus }\end{array}$ & $\begin{array}{l}\text { Cultural } \\
\text { - Avoid host crops in adjoining areas } \\
\text { - Single cotton crop per year } \\
\text { - Preferred crop rotation with Corn, Sorghum or Ragi } \\
\text { - Eradication of weeds } \\
\text { - Proper sanitation of field } \\
\text { - Sticky traps } \\
\text { - Elimination of affected leaves } \\
\text { Chemical: } \\
\text { - Insecticidal sprays (Acetamipirid or Chlorpyriphos) } \\
\text { - Neem oil treatment } \\
\text { Biological: } \\
\text { - Verticillium lecanii }\end{array}$ \\
\hline
\end{tabular}


Table 6. Cotton diseases.

\begin{tabular}{|c|c|c|}
\hline Symptom Type & Disease & Causal Agent \\
\hline \multirow[t]{3}{*}{ Bacterial diseases } & Bacterial blight of cotton & $\begin{array}{l}\text { Xanthomonas citri } \\
\text { Spp. Malvacearum }\end{array}$ \\
\hline & Lint degradation & Erwinia herbicola \\
\hline & Crown gall & Agrobacterium tumefaciens \\
\hline \multirow[t]{9}{*}{ Viral diseases } & Leaf curl & Begomovirus \\
\hline & Leaf crumple & Begomovirus \\
\hline & Mosaic & Begomovirus \\
\hline & Anthocyanosis & Suspicious virus (unknown) \\
\hline & Blue diseases & $\begin{array}{l}\text { Phytoplasma or Suspicious virus } \\
\text { (unknown) }\end{array}$ \\
\hline & Leaf mottle & Suspicious virus (unknown) \\
\hline & Leaf roll & Suspicious virus (unknown) \\
\hline & Terminal stunt & Suspicious virus (unknown) \\
\hline & Psylosis & Suspicious virus (unknown) \\
\hline \multirow[t]{27}{*}{ Fungal diseases } & Anthracnose & $\begin{array}{l}\text { Collectotrichum gossypii } \\
\text { Glomerella gossypii }\end{array}$ \\
\hline & Areolate mildew & Ramularia gossypii \\
\hline & Ascochyta blight & Ascochyta gossypii \\
\hline & Boll rot & Ascochyta gossypii \\
\hline & & Collectotrichum gossypii \\
\hline & & Glomerella gossypii \\
\hline & & Fusarium species \\
\hline & & Lasiodiplodia theobromae \\
\hline & & Physalospora rhodina \\
\hline & & Rhizoctonia solani \\
\hline & & Phytophthora species \\
\hline & Black root rot & Chalara elegans \\
\hline & Cotton root rot & Phymatotrichopsis omnivore \\
\hline & Charcoal rot & Macrophomina phaseolina \\
\hline & Cotton rust & Puccinia schedonnardii \\
\hline & Escobilla & Glomerella gossypii \\
\hline & & Colletotrichum gossypii \\
\hline & Fusarium wilt & Fusarium oxysporum \\
\hline & Leaf spot & Alternaria alternata \\
\hline & & Alternaria macrospora \\
\hline & & Bipolaris spicifera \\
\hline & & Cercosproa gossypina \\
\hline & & Cochliobolus spicifera \\
\hline & & Mychosphaerella gossypina \\
\hline & & Myrothecium roridum \\
\hline & & Rhizoctonia solani \\
\hline & & Stemphylium solani \\
\hline
\end{tabular}




\begin{tabular}{|c|c|c|}
\hline & Lint contamination & $\begin{array}{l}\text { Aspergillus flavus } \\
\text { Nematospora species } \\
\text { Nigrospora oryzae }\end{array}$ \\
\hline & Powdery mildew & $\begin{array}{l}\text { Salmonia malachrae } \\
\text { Leveillula taurica } \\
\text { Oidiopsis gossypii }\end{array}$ \\
\hline & Stigmatomycosis & $\begin{array}{l}\text { Ashbya gossypii } \\
\text { Aureobasidium pullulans } \\
\text { Nematospora coryli }\end{array}$ \\
\hline & Southwest cotton rust & Puccinia cacabata \\
\hline & Tropical cotton rust & Phakopsora gossypii \\
\hline & Southern blight & Athelia rolfsii \\
\hline Fungal seedling diseases & Seedling disease complex & $\begin{array}{l}\text { Colletotrichum gossypii } \\
\text { Calara elegans } \\
\text { Fusraium species } \\
\text { Phythium species } \\
\text { Rhizoctonia solani } \\
\text { Thenatephorus cucumeris } \\
\text { Thielaviopsis Basicola }\end{array}$ \\
\hline & $\begin{array}{l}\text { Stem canker } \\
\text { Verticillium wilt }\end{array}$ & $\begin{array}{l}\text { Phoma exigua } \\
\text { Verticillium dahlia }\end{array}$ \\
\hline Nematodal diseases & $\begin{array}{l}\text { Lance } \\
\text { Root knot } \\
\text { Reniform } \\
\text { Sting }\end{array}$ & $\begin{array}{l}\text { Hoplolaimus Columbus } \\
\text { Meloidogyne incgonita } \\
\text { Rotylenchulus reniform } \\
\text { Belonolaimus longicaudatus }\end{array}$ \\
\hline $\begin{array}{l}\text { Phytoplasma \& } \\
\text { spiroplasma diseases }\end{array}$ & $\begin{array}{l}\text { Phyllody } \\
\text { Small leaf }\end{array}$ & $\begin{array}{l}\text { Suspecious phytoplasma (unknown) } \\
\text { Suspecious phytoplasma (unknown) }\end{array}$ \\
\hline
\end{tabular}

of the virus and its quick evolution and gene recombination [63]. Currently, no variety of $G$. hirsutum is resistant to $\mathrm{CLCuV}$. Current strategies include introducing resistance genes from $G$. arboreum to $G$. hirsutum.

\section{Improvement of Cotton}

Humanity is fed and clothed by several dozen of crops since beginning of time [64]. Man and crops have coevolved in a symbiotic pattern in such a way that survival of both depends on each. For hundreds of years, farmers have used the introduction, genetic variations and selection in wild and cultivated plants to develop the desirous crop [65]. The genetic variation allows the species to cope with and adapt to changing environment, confrontation against pests, diseases and environmental stress [66]. Plant breeding is an art as well as science devoted to improve the heritance and performance of plants involving genetic principles, 
crossing, natural mutation, linkage and selection. Selection is a powerful tool and adopted by human being for propagation of the fittest and well characterized plants. It can be categorized in four stages harboring tillage, sowing, harvesting and propagation [67]. Research conducted on genetic improvement of Acala cultivars and lines released over the past 75 years showed increased yield, fiber strength and length between 1930s and 1960s respectively, as Acala cultivars (Acala 1517-95, 1517-99, 1517-02, 1517-03, and 1517-04) have fiber greater than $30.5 \mathrm{~mm}$ [68]. Selection process become functional upon introduction of wild plants into cultivation: 1) Conscious selection generally applied by the growers to get desired traits; 2) Unconscious/automatic selection included the picking of best fit from its native wild habitat and shifting them into artificial environment (greenhouse) having desired traits are automatically selected to fit over generations. Increased rate of selfing, adaptation of vegetation and seed yield enhancement in different crops have been prominently noted by applying both conscious and unconscious selection [69]. Drought tolerance has been achieved by recurrent selection under drought conditions. Selection of Gossypium barbadense in elevated temperature condition has been resulted into heat tolerance varieties [70].

Natural genetic mutation is also a source of improvement in particular varieties especially oilseed crops. Rape has subsequently been bred into modern oilseed rape and cotton varieties in order to knock out the hazardous chemicals [71] and [72]. In classical plant breeding, linkage is used for transmission of deleterious genes from donors to cultivated plant in order to develop the insect/pest resistance. A morphological mutant having more numbers of monopodial branches in G. hirsutum var; RH-003 when it was treated with $15 \mathrm{kR}$ of gamma rays also beard more number of bolls with elevated size [73]. Induced mutagenesis for improvement of cotton related to characters such as earliness [74], compactness and dwarfism, more boll weight [75], ginning percentage and improved fiber length [76], yield [77], seed oil content [78], resistance against diseases, insect resistance [79], drought and salinity tolerance [80] have been reported.

Cotton is often cross pollinated crop and doesn't suffer from inbreeding depression. Crossing (test cross and back cross) is considered as an effective way to get a plant of interest. Mac7 is identified as resistant cultivar against CLCuD Burewala strain and it was released as a germplasm line by the USDA [81]. It is also an effective measurement for development of plant for better traits. A multiple backcross was performed between Gossypium barbadense L. and G. hirsutum L. observed for QTL analysis for fiber quality. After cross between Guazuncho 2, G. hirsutum, and "VH8", G. barbadense, three backcross generations studied were the $1^{\text {st }}\left(\mathrm{BC}_{1}\right)$ and $2^{\text {nd }}\left(\mathrm{BC}_{2}\right.$ and $\left.\mathrm{BC}_{2} \mathrm{~S}_{1}\right)$ showing fine fiber quality and fiber length [82].

In 1976, Konarev proposed that heterosis is more dominantly manifested in F1 generation and also passed through subsequent generations. It proved supe- 
riority of emerging cultivars regarding disease resistance, elevated yield and tolerance to environmental changes over parental vigor due to recombination phenomenon [83]. In India commercial exploitation of hybrid vigor in cotton was mainly achieved and popularized by cultivation of Hybrid-4 and Varalaxmi at large scale [84]. Improvement in fiber quality, increased number of bolls, halo length and span length of cotton by heterosis were observed [85]. Combining ability generated larger progenies harboring new combinations by hybridization [86]. Genetic variations due to GCA and SCA were significantly noticed for different yield traits in Gossypium hirsutum [87] and [88]. Combining ability (GCA, SCA) plays a significant role for crop improvement through determination of nature and magnitude of gene action and its inheritance. Research conducted on G. hirsutum L. involving a cross between 11 parental plants (MCU5, MCU12, Surabhi and SVPR2 ) as male and seven high oil content genetic accessions (F776, F1861, SOCC11, SOCC17, TCH1641, TCH1644 and TCH1646) were used as female lines had shown the improved cotton yield, bundle strength and optimum seed protein production [89]. Gene action for different non-additive traits including boll weight, boll number, lint $\%$ age and seed cotton yield was observed [90] [91] and [92]. While additive gene action for different traits was observed in upland cotton having genetic effects with enough variability for yield parameter [93] and [94]. Wild relatives of cotton are a critical source of novel genes for breeding programs, particularly for developing biotic and abiotic stress tolerance. Wild cotton specie Gossypium arboreum L. has resistance genes for Begomoviruses causing CLCuD [6], drought [95], heat [95], root rot, CLCuV [63] and insect pests [96]. Interspecific hybridization of cotton has been successful [97]. Nematode resistance was transformed into tetraploid G. hirsutum [98]. Novel genes for resistance to drought and cotton leaf curl disease were introduced into G. hirsutum from G. austral and G. stocksii. As interspecific hybridization of $G$. arboreum and $G$. hirsutum is difficult, some researchers used bridge crosses to introgress resistance genes from wild relatives [99].

Genetically modified cotton has started to reduce strong dependence on pesticides. Bt toxin is a protein naturally produced by the bacterium Bacillus thuringiensis is toxic to some insects, including flies, beetles, butterflies and moths [100] [101] and [102]. Natural insecticide can be produced in cotton tissues by introducing the Bt gene into cotton genome to make Bt cotton. Lepidopteran larvae die after eating leaves of Bt cotton, reducing pesticide use and allowing natural insect predators to dominate and manage the pests. Insecticides are still necessary to control pests that are not affected by Bt toxin, including stink bug, plant bug and aphids. A joint research project by the Chinese Academy of Science, The Center for Chinese Agricultural Policy and Cornell University emphasized the development of resistance in insects against Bt toxin [103]. This statement was later disputed when joint research conducted at Stanford University, the Chinese Academy of Sciences and Rutgers University proposed that Bt cotton can control bollworm and the massive increase in secondary pests was due to increased temperature and precipitation [104]. Pesticide use dropped by 
half after introducing Bt cotton, increasing the numbers of beneficial insects like lacewings, ladybirds and spiders [105] and [106]. Bt cotton was grown on $\sim 25$ mha globally [41], or an estimated $69 \%$ of the total area cultivated in cotton. India is growing the most $\mathrm{Bt}$ cotton in the world, increasing from 50,000 to 10.6 mha from 2002 to 2011 . Bt cotton was $88 \%$ of the total cotton growing area in 2011. Increased yield of Bt cotton cultivation had raised living standards of small farmers in India by 2012 [39]. The second, third and fourth-largest Bt cotton-producing countries are the United States, China and Pakistan at $4 \mathrm{mha}, 3.9$ mha and 2.6 mha, respectively [106]. Cultivating Bt cotton has reduced pesticide use by $88 \%$. Subsequent cultivation of Bt cotton in Australia led it to become the fifth-largest Bt cotton-producing country in 2009 [107]. Other leading Bt cotton-producing countries are Argentina, Brazil, Burkina Faso, Colombia, Costa Rica, Mexico, Myanmar and South Africa. Monsanto developed a Bt cotton resistant to the broad-spectrum herbicide glyphosate. From 1996 to 2011, 62\%, $24 \%$ and $14 \%$ of cultivated cotton worldwide was genetically modified, stacked or herbicide resistant, respectively [106]. Some cotton varieties are now edible because the genes in the gossypol glands that make it toxic have been silenced [108].

\section{Cotton Transformation}

It is an essential and foremost priority of a researcher to develop an efficient and facile transformation system to generate a transgenic plant having unique and novel traits as it can be looked in advanced technologies for plants. The technique must be accessible and handy to use for all plant breeders that can be incurred as a commonly practiced protocol for the generation of desirous plants. Classical breeding is one way to generate covet plant but this technique is time consuming, relentless and involves source plant harboring desired gene [108]. Numerous protocols for transformation have been developed in past decades such as biolistic, micro-injection and electroporation etc. but most of these are tissue culture dependent. Ever since, the first successful genetic transformation accomplished in plants during 1980's [110] and [111] and scientist were looking out for a technique requiring less expertise and technical skills, time and don't involve exorbitant apparatus. Graves and Goldman provided the concept of tissue culture independent plant transformation technique in 1986 and named it as In planta transformation. It gave an edge to all other tissue culture dependent protocols as evading the issue of somaclonal variation and require lesser time to produce T0 plant [109].

In planta transformation technique mainly encompasses Agrobacterium mediated and pollen tube pathway (Arabidopsis thaliana, rice, cotton, wheat, $\mathrm{Me}$ dicago truncatula, Jatropha curcas and so on). In planta method have been successfully practiced using seeds, epicotyls, shoot apical nodes, flowers and fruits as recipient tissues with greater efficiency compared to other tissue culture based protocol [112]. Cotton has been transformed by various protocols (Table 7). Transformation and regeneration of cotyledonary tissues of cotton was first 
Table 7. Cotton transformation events.

\begin{tabular}{|c|c|c|c|c|c|}
\hline Variety & Method & Regeneration capacity & Explant & Year & Reference \\
\hline Coker-201 & Agrobacterium-mediated transformation & $\sqrt{ }$ & Cotyledon & 1987 & Firoozabady et al. \\
\hline Cotton & Particle bombardment & $x$ & Meristem & 1995 & Chlan et al. \\
\hline Guazuncho II & Regeneration & $\sqrt{ }$ & $\begin{array}{c}\text { Embryonic axes of apical } \\
\text { meristems }\end{array}$ & 1998 & Morre et al. \\
\hline Coker-312 & Regeneration & $\sqrt{ }$ & Callus & 2003 & Mishra et al. \\
\hline CIM-443 & Agrobacterium-mediated transformation & $x$ & Cotyledonary nodes & 2004 & Ali et al. \\
\hline Coker-312 & Agrobacterium-mediated transformation & $\sqrt{ }$ & Embryogenic calli & 2004 & Ikram-ul-Haq \\
\hline Coker-201 & Suspension culture & $\sqrt{ }$ & Somatic embryos & 2008 & Jing Lin et al. \\
\hline NC-71 & Agrobacterium-mediated transformation & $x$ & Apical meristem & 2008 & Keshamma et al. \\
\hline Coker-312 & Particle bombardment & $\sqrt{ }$ & Embryo & 2008 & Rech et al. \\
\hline Coker-312 & Agrobacterium-mediated transformation & $\sqrt{ }$ & Flower & 2010 & TianZi et al. \\
\hline HS-6 & Agrobacterium-mediated transformation & $x$ & Embryonic axes & 2011 & Amudha et al. \\
\hline Coker-310 & Agrobacterium-mediated transformation & $\sqrt{ }$ & Somatic embryos & 2014 & Sohrab et al. \\
\hline NIAB-846 & Agrobacterium-mediated transformation & $x$ & $\begin{array}{c}\text { Mature embryos \& shoot } \\
\text { apex }\end{array}$ & 2015 & Bajwa et al. \\
\hline
\end{tabular}

performed in 1987, which regenerated over 80\% of embryos from Agro-transformed calli. Antibiotic resistance, production of opines, immunoassay and Southern blot analysis confirmed positive transformation [113]. A particle bombardment protocol for cotton transformation was optimized using cotton meristems and a Bio-Rad PDS-1000-He gene gun [114]. The role of cytokinins in cotton shoot development was studied by treating embryonic axis of cotton apical meristems with the cytokinin benzyladenine for 2 - 20 days and watching expansion [115]. Benzyladenine was effective at promoting development of shoots and buds [115]. A genotype-independent regeneration protocol for some elite varieties of Gossypium hirsutum was optimized. The high regeneration potential of Riata was due to introgression of potential regeneration alleles (it was a hybrid cross of a Roundup-ready transgenic cultivar and a cultivar with transgenic Maxxa genetic background). Max-R lines with elite genetic background were produced through increased regeneration selection pressure [116]. Apical meristems and cotyledonary nodes were used to induce multiple shoots in CIM-443 [117]. Somaclonal variation and somatic embryogenesis are often barriers to cotton plant regeneration. Genotype, explant, Agrobacterium strain and callus induction medium are the critical parameters for Agrobacterium-mediated transformation. A set can produce transformed cotton plants in eight to 10 months [118]. Agrobacterium mediated transformation of green colored cotton was reported from the Chinese Academy of Sciences [119]. Cotton variety G-9803 showed regeneration of embryogenic callus. G-9803 was transformed with gene (GhExp-1) specific for fiber expansion and tissue culture. A transformation frequency of $17.8 \%$ was observed among 32 distinct regenerants produced within seven months. 
These findings signify the pioneer work for genetic manipulation of green-colored cotton [119]. An Agrobacterium-mediated transformation protocol for Coker-312 used a cDNA (GUS and nptII genes) on two-month-old embryogenic calli derived from hypocotyls. Nearly, $46.6 \%$ and $20 \%$ of explants showed GUS activity after vacuum infiltration and Agrobacterium-mediated transformation. $28.23 \%$ efficiency of transformation was achieved [120]. An efficient method with improved frequency of somatic embryogenesis and concomitant growth of somatic embryos was developed. The combined protocol of suspension and solid culture promoted synchronization of somatic embryogenesis and mass embryo development [121]. Cotton transformation was improved by minimizing tissue culture to avoid recalcitrance [122]. A high-efficiency cotton transformation protocol bombarded embryo with gold microparticles coated with DNA at $0.55 \%$ average frequency of transformation and produced plants in $7-10$ months [123]. A pistil drip method for cotton transformation used a solution carrying Agrobacterium with a plasmid conferring herbicide resistance, showed stable gene integration and heritability [124]. Agrobacterium-mediated transformation was done with antisense CLCuD coat protein RNA resulting in no symptoms of CLCuD in positively transformed plants [125]. Agrobacterium-mediated transformation and somatic embryogenesis were employed to insert the bC1 gene into Coker-310. Transformed plants developed no CLCuD symptoms throughout their life cycle and were deemed resistant to CLCuV [126]. The fiber expansion gene GhEXPA8 was introduced into NIAB846. Transgenic plants had increased expression of GhEXPA8 for fiber length and micronaire value [127]. Pollen tube pathway has been used for development of transgenic cotton to overcome the problem of regeneration owing to recalcitrant nature of cotton [128] (Table 8).

Pollen tube mediated gene transfer (PTT) has the ability to transform foreign DNA through involvement of pollen grain into germ line. PTT has potential benefits as it often forestall the imperfection in reduction of fertility, dependence on genotype, and different genetic variation including mutation/methylation and most important one is that it avoids manipulation, identification and screening of transformants as compared to other protocols [129]. Pollen tube mediated transformation is efficient and simple alternative of producing transgenic plants, evading the stipulations for tissue culture. The PTT method was first reported in cotton (Gossypium hirsutum L.) [130] and rice [131]. Two approaches were used for Pollen tube mediated transformation; pollen grain is used as a vector in first and recent approach. Maize inbreds Zheng 58 and Dika 527 were used and two constructs, plasmid p3301UbiAc have bar gene as selectable marker+ and CrylAc gene while other plasmid pLM01 harboring ampicillin resistant maker gene and eGfp gene. Pollen grains were subjected to ultrasonication which denatured the nuclease without affecting their viability and germination. Pollen grains were used as a vector to carry transgenes by the application of sonication treatments and immersed in sucrose solution. Gene of interest could be incorporated 
Table 8. Traits improved through genetic transformation.

\begin{tabular}{|c|c|c|c|c|c|c|}
\hline Crop & Gene/Trait & $\begin{array}{l}\text { Pollen tube } \\
\text { mediated gene } \\
\text { transfer }\end{array}$ & $\begin{array}{l}\text { Floral Dip } \\
\text { With } A . \\
\text { tumefaciens }\end{array}$ & $\begin{array}{l}\text { A. tumefaciens } \\
\text { mediated gene } \\
\text { transfer }\end{array}$ & $\begin{array}{l}\text { Biolistic } \\
\text { Bombardment }\end{array}$ & References \\
\hline Maize (Zea mays L.) & $\begin{array}{l}\text { LB-UbiP-GFP- } \\
\text { nosT-RB }\end{array}$ & $\begin{array}{l}0.86 \% \text { (3.38\% } \\
\text { with ovary drip) }\end{array}$ & $3.30 \%$ & 5 to 50 & 5 to 40 & $\begin{array}{l}\text { Bennetzen and Hake, 2009; Mu et al., } \\
\text { 2012; Yang et al., } 2009\end{array}$ \\
\hline $\begin{array}{l}\text { Soybean } \\
\text { (Glycine } \max \mathrm{L} . \text {.) }\end{array}$ & $\begin{array}{l}\text { LB-35SP- } \\
\text { smGFP-nosTRB }\end{array}$ & $\begin{array}{l}0.97 \% \text { (3.00\% } \\
\text { with ovary drip) }\end{array}$ & ---- & 4.29 to 18 & 9 & Huang et al., 1999; Zhang et al., 2017 \\
\hline $\begin{array}{l}\text { Cotton (Gossypium } \\
\text { hirsutum L.) }\end{array}$ & $\begin{array}{l}\text { LB-hpt/nptIIRB } \\
\text { (pCAMBIA1301/2301) }\end{array}$ & $15.3 \% \& 1.9 \%$ & $0.7 \%-0.17 \%$ & 15 & 0.71 & $\begin{array}{l}\text { Bibi et al., 2013; TianZi et al., 2010; Ali et } \\
\text { al., 2015; Jin et al., 2005; Rajasekaran, } 2013\end{array}$ \\
\hline $\begin{array}{l}\text { Wheat (Triticum } \\
\text { aestivum } \mathrm{L} . \text {.) }\end{array}$ & 35SP-CryIA-nosT & $1.13 \%$ to $1.21 \%$ & 0.3 to $0.6 \%$ & 1 to 30 & 20 & $\begin{array}{l}\text { Agarwal et al., 2009; Hou et al., 2003; } \\
\text { Risacher et al., 2009; Wright et al., } 2001\end{array}$ \\
\hline $\begin{array}{l}\text { Melon } \\
\text { (Cucumis melo L.) }\end{array}$ & $\begin{array}{l}\text { LB-35SPACO1 } \\
\text { (antisense)-nosTRB }\end{array}$ & $0.70 \%$ & & 0.1 to 10.6 & 1 & $\begin{array}{l}\text { Castelblanque et al., 2008; Gaba et al., } \\
\text { 1992; Hao et al., } 2011\end{array}$ \\
\hline $\begin{array}{l}\text { Watermelon } \\
\text { (Citrullus lanatus } \\
\text { Thumb.) }\end{array}$ & $\begin{array}{l}\text { 35SP-GUS-nosT-Squas } \\
\text { h DNA }\end{array}$ & $5.00 \%$ & & 10.28 & 1 to 17 & $\begin{array}{l}\text { Chen et al., 1998; Li et al., 2012; } \\
\text { Suratman et al., } 2010\end{array}$ \\
\hline $\begin{array}{l}\text { Papaya } \\
\text { (Cariza Papaya L.) }\end{array}$ & $\begin{array}{l}\text { 35SP-PRSVCPPRSVCP } \\
\text { (antisense)ocsT }\end{array}$ & $8.90 \%$ & & 1.6 to 26.3 & 27 & $\begin{array}{l}\text { Jiang et al., 2004; Souza Júnior, 2005; } \\
\text { Wei et al., } 2008\end{array}$ \\
\hline $\begin{array}{l}\text { Walnut } \\
\text { (Juglans regia L.) }\end{array}$ & $\begin{array}{l}\text { LB-nosT-GUS-UbiP- } \\
\text { 35SHPT-nosT-RB }\end{array}$ & $20.70 \%$ & & 15 & & Bosela et al., 2004; Shi et al., 2012 \\
\hline $\begin{array}{l}\text { Onion } \\
\text { (Allium cepa L.) }\end{array}$ & 35SP-Luciferase-nos T & $12 \%$ to $5 \%$ & & 1.95 & 4.67 & $\begin{array}{l}\text { Peffley et al., 2003; Xu et al., 2014; Zheng } \\
\text { et al., } 2001\end{array}$ \\
\hline
\end{tabular}

as a naked DNA or through Agrobacterium. Mature pollen develop a vegetative cell and a generative cell and pass through mitosis for the formation of two male gametes. Transgene is incorporated into generative cell which fuse to egg cell through the way of pollen tube ultimately for the formation of zygote. For foreign DNA incorporation, vacuum infiltration or gene gun can be employed [132]. Targeted pollen having genes of interest are transferred to recipient plant at embryo forming stage through the process of pollination [133]. Secondary approach is the process of transformation in recipient plant; the stigma is removed shortly after pollination from style. Solution of exogenous DNA is applied directly to ovary as transgene reaches the ovule and fertilize it, leading to the formation of zygote, the whole process is carried in a natural manner [134].

Multinational companies have transformed various cotton varieties for commercial use with traits including insect pest and herbicide resistance (Table 9).

\section{Conclusion}

During current era, there has been an intense need for developing improved cotton varieties to meet the ever growing demands of fine quality and sophisticated clothes. Crop improvement has been shifted from conventional breeding approaches towards manipulating the genome of cotton plant precisely without leaving marks of antibiotic resistance genes within the genome. A broad view of 
Table 9. GM Cotton.

\begin{tabular}{ccc}
\hline Company & Resistance Trait & Date of Approval \\
\hline Monsanto & Glufosinate \& Dicamba & $20^{\text {th }}$ Jan 2015 \\
Bayer Crop Science & Moth \& butterfly Glufosinate & $22^{\text {nd }}$ Feb 2013 \\
Bayer Crop Science & Moth \& butterfly Glufosinate & $12^{\text {th }}$ Oct 2011 \\
Syngenta & Moth \& butterfly & $29^{\text {th }}$ Sep 2011 \\
Bayer Crop Science & Herbicide & $22^{\text {nd }}$ May 2009 \\
Syngenta & Moth \& butterfly & $6^{\text {th }}$ July 2005 \\
Monsanto & Herbicide & $20^{\text {th }}$ Dec 2004 \\
Dow/Mycogen & Moth \& butterfly & $15^{\text {th }}$ July 2004 \\
Aventis & Phosphinothericine & $10^{\text {th }}$ March 2003 \\
Monsanto & Moth \& butterfly & $5^{\text {th }}$ Nov 2002 \\
Calgene & Bromooxynill, Moth \& butterfly & $30^{\text {th }}$ April 1997 \\
Du Pont Pioneer & Sulfonylurea & $25^{\text {th }}$ Jan 1996 \\
Monsanto & Herbicide & $11^{\text {th }}$ July 1995 \\
Monsanto & Moth \& butterfly & $22^{\text {nd }}$ June 1995 \\
Calgene & Bromooxynill & $15^{\text {th }}$ Feb 1994 \\
\hline
\end{tabular}

each and every aspect of cotton plant has been presented in this review to help researchers pinpoint the traits and modify its genome precisely. Increased cotton production will not only fulfill the needs of growing world's population but will also strengthen the textile economy.

\section{Future Directions}

Cotton transformation towards improvement of traits for yield, quality and beyond will be the future goal of cotton breeders and biotechnologists. Marker free plants will be produced to lessen the impact caused by antibiotics to the entire ecosystem.

\section{Author's Contribution}

Sabin Aslam wrote the main manuscript, drawn all figures and tables. Sultan Habibullah Khan prepared the main outline and edited primary draft of manuscript. Abhaya M. Dandekar edited the manuscript extensively. Aftab Ahmed gave valuable suggestions to improve manuscript. All authors read final copy and approved the manuscript.

\section{Acknowledgements}

The work is supported by Higher Education Commission of Pakistan's PhD Indigenous scholarship granted to Sabin Aslam. All suggestions, outcomes, pronouncements and inferences revealed in manuscript are of author(s) and doesn't reflect perspective of Higher Education Commission of Pakistan. 


\section{Conflicts of Interest}

There is no conflict of interest for this article.

\section{References}

[1] http://www.worldatlas.com/articles/top-cotton-producing-countries-in-the-world.h $\underline{\mathrm{tml}}$

[2] USDA-NASS (2017).

[3] http://www.cotton.org/econ/world

[4] Oskawe, E. (2009) Cotton Fact Sheet. International Cotton Advisory Committee.

[5] Banuri, T. (1998) Pakistan: Environmental Impact of Cotton Production and Trade. Int. Institute of Sustainable Development, Canada.

[6] Cororaton, C.B. and Orden, D. (2008) Pakistan's Cotton and Textile Economy, Intersectoral Linkages and Effects on Rural and Urban Poverty. International Food Policy Research Institute, USA.

[7] Economic Survey of Pakistan (2017) Ministry of Food, Agriculture and Livestock, Economic Advisor Wing, Islamabad, Pakistan.

[8] (2008) The Biology of Gossypium hirsutum L. and Gossypium barbedense L. (Cotton). Australian Government, Department of Health and Ageing, Office of the Gene Technology Regulator. Version 2, 1-91. http://www.ogtr.gov.au

[9] Quinn, J. and Kelly, D. (2011) Australian Cotton Production Manual. Crop Growth Stages, 7, 44-47.

[10] Robertson, B., Bednarz, C. and Burmester, C. (2007) Growth and Development-First 60 Days. Newsletter of the Cotton Physiology Education Program. National Cotton Council, 13, 1-5.

[11] Oosterhuis, D.M. and Snider, J.L. (2010) High Temperature Stress on Floral Development and Yield of Cotton. In: High Temperature Stress on Floral Development and Yield of Cotton, National Cotton Council of America.

https://www.cotton.org/foundation/upload/Stress-Physiology-in-Cotton Chapter1. pdf

[12] Wendel, J.F., Brubaker, C., Alvarez, I., Cronn, R. and Stewart, J.M. (2009) Evolution and Natural History of the Cotton Genus. In: Paterson, A.H., Ed., Genetics and Genomics of Cotton. Plant Genetics and Genomics: Crops and Models, Vol. 3, Springer, New York, 3-22. https://doi.org/10.1007/978-0-387-70810-2 1

[13] Schmitz, U. (2009) David Gledhill (2008): The Names of Plants. Flora, 204, 560. https://doi.org/10.1016/j.flora.2008.11.002

[14] Wendel, J.F. and Grover, C.E. (2015) Taxonomy and Evolution of the Cotton Genus, Gossypium. In: Cotton, 2, American Society of Agronomy, Inc., Crop Science Society of America, Inc., Soil Science Society of America, Inc., 1-20.

https://doi.org/10.2134/agronmonogr57.2013.0020

[15] Chen, Z.J., Scheffler, B.E., Dennis, E., Triplett, B.A., Zhang, T., Guo, W., Chen, X., Stelly, D.M., Rabinowicz, P.D., Town, C.D., Arioli, T., Brubaker, C., Cantrell, R.G., Lacape, J., Ulloa, M., Chee, P., Gingle, A.R., Haigler, C.H., Percy, R., Saha, S., Wilkins, T., Wright, R.J., Deynze, A.V., Zhu, Y., Yu, S., Abdurakhmonov, I., Katageri, I., Kumar, P.A., Rahman, M., Zafar, Y., Yu, J.Z., Kohel, R.J., Wendel, J.F. and Paterson, A.H. (2007) Towards Sequencing Cotton (Gossypium) Genomes. Plant Physiology, 145, 1303-1310. https://doi.org/10.1104/pp.107.107672

[16] Duncan, D.R. (2010) Cotton Transformation. In: Cotton. Biotechnology in Agri- 
culture and Forestry, Vol. 65, Springer, Berlin, Heidelberg. https://doi.org/10.1007/978-3-642-04796-1 4

[17] Schoen, B. (2009) The Fragile Fabric of Union: Cotton, Federal Politics and the Global Origins of the Civil War. Johns Hopkins University Press, Baltimore, MD, 26-31.

[18] Zafar, Y. and Brown, J. (2011) Genome Characterization of Whitefly-Transmitted Geminivirus of Cotton and Development of Virus-Resistant Plants through Genetic Engineering and Conventional Breeding. The ICAC Recorder, 29, 7-12.

[19] Kirkby, K.A., Lonergan, P.A., Smith, L.J., Scheikowski, L., Cooper, B.R. and Lehane, J. (2012) Innovative Disease Management.

[20] http://www.cotton.org/tech/ace/growth-and-development.cfm

[21] Oliver, T.W. (2013) King Cotton in Albama: A Brief History.

[22] Brite, E. and Marston, J.M. (2013) Environmental Change, Agricultural Innovation, and the Spread of Cotton Agriculture in the Old World. Journal of Anthropology and Archaeology, 32, 39-53. https://doi.org/10.1016/j.jaa.2012.08.003

[23] (2007) Cotton, A History. https://newint.org/features/2007/04/01/history

[24] Murphy, J.D. (2007) People, Plants and Genes: The Story of Crops and Humanity. Oxford University Press, Oxford.

[25] Moulherat, C., Tengberg, M., Haquet, J.F. and Mille, B. (2002) First Evidence of Cotton at Neolithic Mehrgarh, Pakistan: Analysis of Mineralized Fibres from a Copper Bead. Journal of Archaeological Science, 29, 1393-1401. https://doi.org/10.1006/jasc.2001.0779

[26] Burton, S. (1998) A History of India. Blackwell Publishing, Hoboken, NJ.

[27] Ahmed, M. (2014) Ancient Pakistan-An Archaeological History. CreateSpace Independent Publishing, Scotts Valley, CA.

[28] Osada, T. and Uesugi, A. (2008) Linguistics, Archaeology and the Human Past. Research Institute for Humanity and Nature, Kyoto.

[29] Hustvedt, G. and Crew, P.C. (2005) Textile Technology. The Journal of Cotton Science, 9, 47-55.

[30] Fox, S. (2009) Natural Cotton.

[31] Vreeland Jr., J.M. (1999) The Revival of Colored Cotton. Scientific American, 280, 112. https://doi.org/10.1038/scientificamerican0499-112

[32] Malik, W., Khan, A.A. and Sadia, B. (2013) In Situ Characterization of Coloured Cotton Genotypes. Australian Journal of Crop Science, 7, 299-304.

[33] Khan A.I., Fu, Y.B. and Khan, I.A. (2009) Genetic Diversity of Pakistani Cotton Cultivars as Revealed by Simple Sequence Repeat Markers. Communications in Biometry and Crop Science, 4, 21-30.

[34] http://www.cicr.org.in/

[35] Guo, W.Z., Wang, K. and Zhang, T.Z. (2003) A and D Genome Evolution in Gossypium Revealed Using SSR Molecular Markers. Journal of Genetics and Genomics, 30, 183-188.

[36] Zhao, X., Ji, Y., Ding, X., Stelly, D.M. and Paterson, A.H. (1998) Macromolecular Organization and Genetic Mapping of a Rapidly Evolving Chromosome-Specific Tandem Repeat Family (B77) in Cotton (Gossypium). Plant Molecular Biology, 38, 1031-1042. https://doi.org/10.1023/A:1006073116627

[37] Page, J.T., Huynu, M.D., Liechty, Z.S., Grupp, K., Hulse, A.M., Ashrafi, H., Van-Deynze, A., Wendel, J.F. and Udall, J.A. (2013) Insights into the Evolution of 
Cotton Diploids and Polyploids from Whole-Genome Re-Sequencing. G3, 3, 1809-1818. https://doi.org/10.1534/g3.113.007229

[38] Wang, K., Wang, Z., Li, F., Ye, W., Wang, J., Song, G., Yue, Z., Cong, L., Shang, H., Zhu, S., Zou, C., Li, Q., Yuan, Y., Lu, C., Wei, H., Gou, C., Zheng, Z., Yin, Y., Zhang, X., Liu, K., Wang, B., Song, C., Shi, N., Kohel, R.J., Percy, R.G., Yu, J.Z., Zhu, Y.X., Wang, J. and Yu, S. (2012) The Draft Genome of a Diploid Cotton Gossypium raimondii. Nature Genetics, 44, 1098-1103. https://doi.org/10.1038/ng.2371

[39] http://www.isaaa.org/kc/cropbiotechupdate/article/default.asp?ID=6723

[40] Guo, W., Cai, C., Wang, C., Zhao, L., Wang, L. and Zhang, T. (2008) A Preliminary Analysis of Genome Structure and Composition in Gossypium hirsutum. BMC Genomics, 9, Article No. 314. https://doi.org/10.1186/1471-2164-9-314

[41] Paterson, A.H., Wendel, J.F., Gundlach, H., Guo, H., Jenkins, J., Jin, D., Llewellyn, D., Showmaker, K.C., Shu, S., Udall, J., Yoo, M.J., Byers, R., Chen, W., Doron-Faigenboim, A., Duke, M.V., Gong, L., Grimwood, J., Grover, C., Grupp, K., Hu, G., Lee, T.H., Li, J., Lin, L., Liu, T., Marler, B.S., Page, J.T., Roberts, A.W., Romanel, E., Sanders, W.S., Szadkowski, E., Tan, X., Tang, H., Xu, C., Wang, J., Wang, Z., Zhang, D., Zhang, L., Ashrafi, H., Bedon, F., Bowers, J.E., Brubaker, C.L., Chee, P.W., Das, S., Gingle, A.R., Haigler, C.H., Harker, D., Hoffmann, L.V., Hovav, R., Jones, D.C., Lemke, C., Mansoor, S., Rehman, M., Rainville, L.N., Rambani, A., Reddy, U.K., Rong, J.K., Saranga, Y., Scheffler, B.E., Scheffler, J.A., Stelly, D.M., Triplet, B.A., Deynze, A.V., Vaslin, M.F., Waghmare, V.N., Walford, S.A., Wright, R.J., Zaki, E.A., Zhang, T., Dennis, E.S., Mayer, K.F., Peterson, D.G., Rokhsar, D.S., Wang, X. and Schmutz, J. (2012) Repeated Polyploidization of Gossypium Genomes and the Evolution of Spinnable Cotton Fibres. Nature, 492, 423-427.

https://doi.org/10.1038/nature11798

[42] Wang, Z., Zhang, D., Wang, X., Tan, X., Guo, H. and Paterson, A.H. (2013) A Whole-Genome DNA Marker Map for Cotton Based on the D-Genome Sequence of Gossypium raimondii L. G3, 3, 1759-1767. https://doi.org/10.1534/g3.113.006890

[43] Blenda, A., Fang, D.D., Rami, J.F., Garsmeur, O., Luo, F. and Lacape, J.M. (2012) A High Density Consensus Genetic Map of Tetraploid Cotton That Integrates Multiple Component Maps through Molecular Marker Redundancy Check. PLoS ONE, 7, e45739. https://doi.org/10.1371/journal.pone.0045739

[44] Xie, W., Feng, Q., Yu, H., Huang, X., Zhao, Q., Xing, Y., Yu, S., Han, B. and Zhang, Q. (2010) Parent-Independent Genotyping for Constructing an Ultrahigh-Density Linkage Map Based on Population Sequencing. Proceedings of the National Academy of Sciences of the United States of America, 107, 10578-10583. https://doi.org/10.1073/pnas.1005931107

[45] Sun, Z., Wang, Z., Tu, J., Zhang, J. and Yu, F. (2007) An Ultradense Genetic Recombination Map for Brassica napus, Consisting of 13,551 SRAP Markers. Theoretical and Applied Genetics, 114, 1305-1317. https://doi.org/10.1007/s00122-006-0483-Z

[46] Li, F., Fan, G., Wang, K., Sun, F., Yuan, Y., Song, G., Li, Q., Ma, Z., Lu, C., Zou, C., Chen, W., Liang, X., Shang, H., Liu, W., Shi, C., Xiao, G., Gou, C., Ye, W., Xu, X., Zhang, X., Wei, H., Li, Z., Zhang, G., Wang, J., Liu, K., Kohels, R.J., Percy, R.G., Yu, J.Z., Zhu, Y., Wang, J. and Yu, S. (2014) Genome Sequence of the Cultivated Cotton Gossypium arboreum. Nature Genetics, 46, 567-572. https://doi.org/10.1038/ng.2987

[47] Li, F., Fan, G., Lu, C., Xiao, G., Zou, C., Kohel, R.J., Ma, Z., Shang, H., Ma, X., Wu, J., Liang, X., Huang, G., Percy, R.G., Liu, K., Yang, W., Chen, W., Du, X., Shi, C., Yuan, Y., Ye, W., Liu, X., Zhang, X., Liu, W., Wei, H., Wei, S., Huang, G., Zhang, 
X., Zhu, X., Zhang, H., Sun, F., Wang, X., Liang, J., Wang, J., He, Q., Hunag, L., Wang, J., Cui, J., Song, G., Wang, K., Xu, X., Yu, J.Z., Zhu, Y. and Yu, S. (2015) Genome Sequence of Cultivated Upland Cotton (Gossypium hirsutum TM-1) Provides Insights into Genome Evolution. Nature Biotechnology, 33, 524-530. https://doi.org/10.1038/nbt.3208

[48] Hendrix, B. and Stewart, J.M. (2005) Estimation of the Nuclear DNA Content of Gossypium Species. Annals of Botany, 95, 789-797. https://doi.org/10.1093/aob/mci078

[49] Zhang, T., Hu, Y., Jiang, W., Fang, L., Guan, X., Chen, J., Zhang, J., Saski, C.A., Scheffler, B.E., Stelly, D.M., Hulsekemp, A.M., Wan, Q., Liu, B., Liu, C., Wang, S., Pan, M., Wang, Y., Wang, D., Ye, W., Chang, L., Zhang, W., Song, Q., Kirkbride, R.C., Chen, X., Dennis, E., Llewellyn, D.J., Peterson, D.G., Thaxton, P., Jones, D.C., Wang, Q., Xu, X., Zhang, H., Wu, H., Zhou, L., Mei, G., Chen, S., Tian, Y., Xiang, D., Li, X., Ding, J., Zuo, Q., Tao, L., Liu, Y., Li, J., Lin, Y., Hui, Y., Cao, Z., Cai, C., Zhu, X., Jiang, Z., Zhou, B., Guo, W., Li, R. and Chen, J. (2015) Sequencing of Allotetraploid Cotton (Gossypium hirsutum L. acc. TM-1) Provides a Resource for Fiber Improvement. Nature Biotechnology, 33, 531-537.

https://doi.org/10.1038/nbt.3207

[50] Liu, X., Zhao, B., Zheng, H.J., Hu, Y., Lu, G., Yang, C. Q., Chen, J.D., Chen, J.J., Chen, D.Y., Zhang, L., Zhou, Y., Wang, L.J., Guo, W.Z., Bai, Y.L., Ruan, J.X., Shangguan, X.X., Mao, Y.B., Shan, C.M., Jiang, J.P., Zhu, Y.Q., Jin, L., Kang, H., Chen, S.T., He, X.L., Wang, R., Wang, Y.Z., Chen, J., Wang, L.J., Yu, S.T., Wang, B.Y., Wei, J., Song, S.C., Lu, X.Y., Gao, Z.C., Gu, W.Y., Deng, X., Ma, D., Wang, S., Liang, W.H., Fang, L., Cai, C.P., Zhu, X.F., Zhou, B.L., Chen, Z.J., Xu, S.H., Zhang, Y.G., Wang, S.Y., Zhang, T.Z., Zhao, G.P. and Chen, X.Y. (2015) Gossypium barbadense Genome Sequence Provides Insight into the Evolution of Extra-Long Staple Fiber and Specialized Metabolites. Scientific Reports, 5, Article No. 14139. https://doi.org/10.1038/srep14139

[51] Wang, B.-H., Wu, Y.-T., Huang, N.-T., Zhu, X.-F., Guo, W.-Z. and Zhang, T.-Z. (2006) QTL Mapping for Plant Architecture Traits in Upland Cotton Using RILs and SSR Markers. Acta Genetica Sinica, 33, 161-170. https://doi.org/10.1016/S0379-4172(06)60035-8

[52] Abdurakhmonov, I.Y., Kohel, R.J., Yu, J.Z., Pepper, A.E., Abdullaev, A.A., Kushanov, F.N., Salakhutdinov, I.B., Buriev, Z.T., Saha, S., Scheffler, B.E., Jenkins, J.N and Abdukarimov, A. (2008) Molecular Diversity and Association Mapping of Fiber Quality Traits in Exotic G. hirsutum L. Germplasm. Genomics, 92, 478-487. https://doi.org/10.1016/j.ygeno.2008.07.013

[53] de Magalhães Bertini, C.H.C., Schuster, I., Sediyama, T., de Barros, E.G. and Moreira, M.A. (2006) Characterization and Genetic Diversity Analysis of Cotton Cultivars Using Microsatellites. Genetics and Molecular Biology, 29, 321-329. https://doi.org/10.1590/S1415-47572006000200021

[54] Chen, G. and Du, X.-M. (2006) Genetic Diversity of Source Germplasm of Upland Cotton in China as Determined by SSR Marker Analysis. Acta Genetica Sinica, 33, 733-745. https://doi.org/10.1016/S0379-4172(06)60106-6

[55] Tyagi, P., Gore, M.A., Bowman, D.T., Campbell, B.T., Udall, J.A. and Kuraparthy, V. (2014) Genetic Diversity and Population Structure in the US Upland Cotton (Gossypium hirsutum L.). Theoretical and Applied Genetics, 127, 283-295. https://doi.org/10.1007/s00122-013-2217-3

[56] Ehsan, B., Haque, A., Younas, M., Shaheen, T., Huma, T., Sattar, S., Idrees, S. and Iqbal, Z. (2013) Assessment of Genomic Diversity of Cotton (Gossypium hirsutum) 
Genotypes Using Simple Sequence Repeats Markers through Genetic Analysis Software. International Journal of Agriculture and Biology, 15, 968-972.

[57] Nazeer, W., Ahmad, S., Mahmood, K., Tipu, A.L., Mahmood, A. and Zhao, B. (2014) Introgression of Genes for Cotton Leaf Curl Virus Resistance and Increased Fiber Strength from Gossypium stocksii into Upland Cotton (G. hirsutum). Genetics and Molecular Research, 13, 1133-1143.

https://doi.org/10.4238/2014.February.21.2

[58] Mann, R. (2011) Bemisia tabaci Interaction with Cotton Leaf Curl Virus. In: Thompson, W.M.O., Ed., The Whitefly, Bemisia tabaci (Homoptera: Aleyrodidae) Interaction with Geminivirus-Infected Host Plants, Springer, Dordrecht, 69-88. https://doi.org/10.1007/978-94-007-1524-0 4

[59] Singh, D., Gill, J.S., Gumber, R.K., Singh, R. and Singh, S. (2013) Yield and Fibre Quality Associated with Cotton Leaf Curl Disease of Bt-Cotton in Punjab. Journal of Environmental Biology, 34, 113-116.

[60] Ahmad, S., Hussain, A., Hanif, M., Mahmood, K. and Nazeer, W. (2012) CRSM-38, a New High Yielding Coupled with CLCuV Tolerance Cotton (Gossypium hirsutum L.) Variety. African Journal of Biotechnology, 11, 4368-4677.

[61] Cai J.H., Xie, K., Lin, L., Qin, B.X., Chen, B.S., Meng, J.R. and Liu, Y.L. (2010) Cotton Leaf Curl Multan Virus Newly Reported to Be Associated with Cotton Leaf Curl Disease in China. Plant Pathology, 59, 794-795.

https://doi.org/10.1111/j.1365-3059.2010.02266.x

[62] Sattar M.N., Kvarnheden, A., Saeed, M. and Briddon, R.W. (2013) Cotton Leaf Curl Disease-An Emerging Threat to Cotton Production Worldwide. Journal of General Virology, 94, 695-710. https://doi.org/10.1099/vir.0.049627-0

[63] Azhar, M.T., Akhtar, S. and Mansoor, S. (2012) Cotton Leaf Curl Multan Betasatellite Strains Cloned from Gossypium barbadense Further Supports Selection Due to Host Resistance. Virus Genes, 45, 402-405. https://doi.org/10.1007/s11262-012-0766-1

[64] Kirda, C., Topcu, S., Cetin, M., Dasgan, H., Kaman, H., Topaloglu, F., Derici, M.R. and Ekici, B. (2007) Prospects of Partial Root Zone Irrigation for Increasing Irrigation Water Use Efficiency of Major Crops in the Mediterranean Region. Annals of Applied Biology, 150, 281-291. https://doi.org/10.1111/j.1744-7348.2007.00141.x

[65] Ellstrand, N.C., Prentice, H.C. and Hancock, J.F. (1999) Gene Flow and Introgression from Domesticated Plants into Their Wild Relatives. Annual Review of Ecology and Systematics, 30, 539-563. https://doi.org/10.1146/annurev.ecolsys.30.1.539

[66] Bull, J.J. and Wichman, H.A. (2001) Applied Evolution. Annual Review of Ecology and Systematics, 32, 183-217. https://doi.org/10.1146/annurev.ecolsys.32.081501.114020

[67] Allard, R.W. (1999) History of Plant Population Genetics. Annual Review of Genetics, 33, 1-27. https://doi.org/10.1146/annurev.genet.33.1.1

[68] Zhang, J., Lu, Y., Adragna, H. and Hughs, E. (2005) Genetic Improvement of New Mexico Acala Cotton Germplasm and Their Genetic Diversity. Crop Science, 45, 2363-2373. https://doi.org/10.2135/cropsci2005.0140

[69] Ulukan, H. (2009) The Evolution of Cultivated Plant Species: Classical Plant Breeding versus Genetic Engineering. Plant Systematics and Evolution, 280, 133-142. https://doi.org/10.1007/s00606-008-0118-8

[70] Poelhman, J. and Sleeper, D. (1995) Breeding Cotton. Breeding Field Crops. 4th Edition, Iowa State University Press, Iowa. 
[71] Doebley, J.F., Gaut, B.S. and Smith, B.D. (2006) The Molecular Genetics of Crop Domestication. Cell, 127, 1309-1321. https://doi.org/10.1016/j.cell.2006.12.006

[72] Ulukan, H. (2008) Agronomic Adaptation of Some Field Crops: A General Approach. Journal of Agronomy and Crop Science, 194, 169-179. https://doi.org/10.1111/j.1439-037X.2008.00306.x

[73] Jagtap, D. and Mehetre, S. (1998) Genetic Variability in Intervarietal Crosses of Upland Cotton (Gossypium hirsutum L.). Annals of Agricultural Sciences, 19, 130-132.

[74] Swami, V. and Swami, V. (1986) Effect of Recurrent Selfing and Selection on Plant Type Induced Mutants from Desi Cotton ( $G$. arboreum L.). Madras Agricultural Journal, 73, 66-72.

[75] Sundaravadivelu, K. (2000) Breeding and Induced Mutation Studies in Cultivated Cotton (Gossypium hirsutum L.).

[76] Mehetre, S. and Thombre, M. (1983) Fibre Properties of X-Ray Induced Glandless Mutants in American Cotton. Journal of Maharashtra Agricultural Universities, 8, 189-190.

[77] Iqbal, S., Chaudhry, R., Aslam, M. and Bandesha, A. (1994) Development of a High Yielding Cotton Mutant, NIAB-92 through the Use of Induced Mutations. Pakistan Journal of Botany, 26, 99-99.

[78] Narayanan, S. and Sreerangasamy, S. (1973) Fibre Properties in Diploids and Induced Amphiploids of Asiatic Cotton $\times$ G. anomalum. Madras Agricultural Journal, 60, 1574-1580.

[79] Russell, G.E. (2013) Plant Breeding for Pest and Disease Resistance: Studies in the Agricultural and Food Sciences. Butterworth-Heinemann, UK.

[80] Kharkwal, M. and Shu, Q. (2009) The Role of Induced Mutations in World Food Security. Induced Plant Mutations in the Genomics era. FAO, Rome, 33-38.

[81] Rahman, M., Khan, A.Q., Rahmat, Z., Iqbal, M.A. and Zafar, Y. (2017) Genetics and Genomics of Cotton Leaf Curl Disease, Its Viral Causal Agents and Whitefly Vector: A Way Forward to Sustain Cotton Fiber Security. Frontiers in Plant Science, 8 , 1157. https://doi.org/10.3389/fpls.2017.01157

[82] Lacape, J.-M., Nguyen, T.-B., Courtois, B., Belot, J.-L., Giband, M., Gourlot, J.-P., Gawryziak, G., Roques, S. and Hau, B. (2005) QTL Analysis of Cotton Fiber Quality Using Multiple Gossypium hirsutum $\times$ Gossypium barbadense Backcross Generations. Crop Science, 45, 123-140. https://doi.org/10.2135/cropsci2005.0123a

[83] Srivastava, H.K. (1981) Intergenomic Interaction, Heterosis, and Improvement of Crop Yield. Advances in Agronomy, 34, 117-195. https://doi.org/10.1016/S0065-2113(08)60886-X

[84] Gupta, S. and Singh, T. (1987) Heterosis and Inbreeding Depression for Seed Cotton Yield and Some Seed and Fibre Attributes in Upland Cotton (Gossypium hirsutum L.). Crop Improvement, 14, 14-17.

[85] Alkuddsi, Y., Patil, S., Manjula, S., Patil, B., Nadaf, H. and Nandihali, B. (2013) Heterosis Performance of Seed Cotton Yield and Physiological Parameters in $\mathrm{F}_{1}$ Inter Specific Hybrids in Cotton. Cotton Genomics and Genetics, 4, 60-72.

[86] Basal, H., Canavar, O., Khan, N.U. and Cerit, C.S. (2011) Combining Ability and Heterotic Studies through Line $\times$ Tester in Local and Exotic Upland Cotton Genotypes. Pakistan Journal of Botany, 43, 1699-1706.

[87] Ali, M. and Kalwar, M. (2000) Breeding Implications from a Diallel Analysis for Yield and Yield Components in Cotton. Pakistan Journal of Agriculture, Agricul- 
tural Engineering Veterinary Sciences, 16, 14-18.

[88] Baloch, M.J., Bhutto, H. and Lakho, A.R. (1997) Combining Ability Estimates of Highly Adapted Tester Lines Crossed with Pollinator Inbreds of Cotton (Gossypium hirsutum L.). Pakistan Journal of Scientific and Industrial Research, 40, 95-98.

[89] Ashokkumar, K. and Ravikesavan, R. (2008) Genetic Studies of Combining Ability Estimates for Seed Oil, Seed Protein and Fibre Quality Traits in Upland Cotton ( $G$. hirsutum L.). Research Journal of Agriculture and Biological Sciences, 4, 798-802.

[90] Ahuja, S. and Dhayal, L. (2007) Combining Ability Estimates for Yield and Fiber Quality Traits in $4 \times 13$ Line $\times$ Tester Crosses of Gossypium hirsutum. Euphytica, 153, 87-98. https://doi.org/10.1007/s10681-006-9244-y

[91] Hassan, G., Mahmood, G., Khan, N. and Razzaq, A. (1999) Combining Ability and Heterobeltiotic Estimates in a Diallel Cross of Cotton (Gossypium hirsutum L.). Sarhad Journal of Agriculture, 15, 563-568.

[92] Muthu, R., Kandasamy, G., Raveendran, T., Ravikesavan, R. and Jayaramachandran, M. (2005) Combining Ability and Heterosis for Yield Traits in Cotton (G. hirsutum). Madras Agricultural Journal, 92, 17-22.

[93] Chinchane, V., Kale, U., Chandankar, G., Chinchane, B. and Sarang, D. (2002) Studies on Combing Ability in Cotton (Gossypium hirsutum L.). Annals of Plant Physiology, 16, 160-165.

[94] Lukonge, E.P., Labuschagne, M.T. and Herselman, L. (2008) Combining Ability for Yield and Fibre Characteristics in Tanzanian Cotton Germplasm. Euphytica, 161, 383-389. https://doi.org/10.1007/s10681-007-9587-z

[95] Maqbool, A., Zahur, M., Irfan, M., Qaiser, U., Rashid, B., Husnain, T. and Riazuddin, S. (2007) Identification, Characterization and Expression of Drought Related alpha-Crystalline Heat Shock Protein Gene (GHSP26) from Desi Cotton. Crop Science, 47, 2437-2444. https://doi.org/10.2135/cropsci2007.03.0120

[96] Mansoor, S., Amin, I., Iram, S., Hussain, M., Zafar, Y., Malik, K.A. and Briddon, R.W. (2003) Breakdown of Resistance in Cotton to Cotton Leaf Curl Disease in Pakistan. Plant Pathology, 52, 784. https://doi.org/10.1111/j.1365-3059.2003.00893.x

[97] Armao, L., Akhtar, S., Tahir, N. and Mansoor, S. (2010) Cotton Leaf Curl Disease in Sindh Province of Pakistan Is Associated with Recombinant Begomovirus Components. Virus Research, 153, 161-165. https://doi.org/10.1016/j.virusres.2010.07.003

[98] Sacks, E.J. and Robinson, A.F. (2009) Introgression of Resistance to Reniform Nematode (Rotylenchulus reniformis) into Upland Cotton (Gossypium hirsutum) from Gossypium arboreum and a G. hirsutum/Gossypium aridum Bridging Line. Field Crops Research, 112, 1-6. https://doi.org/10.1016/j.fcr.2009.01.006

[99] Mergcai, G., Baudoin, J.P. and Vroh, B.I. (1997) Exploitation of Trispecific Hybrids to Introgress the Glandless Seed and Glanded Plant Trait of Gossypium sturtianum Willis into Gossypium hirsutum L. Biotechnology, Agronomy, Society and Environment, 1, 272-277.

[100] Hellmich, R.L., Siegfried, B.D., Sears, M.K., Stanely-Horn, D.E., Daniels, M.J., Mattila, H.R., Spencer, T., Bidne, K.G. and Lewis, L.C. (2001) Monarch Larvae Sensitivity to Bacillus thuringiensis-Purified Proteins and Pollen. Proceedings of the National Academy of Sciences of the United States of America, 98, 11925-11930. https://doi.org/10.1073/pnas.211297698

[101] Mendelsohn, M., Kough, J., Vaituzis, Z. and Matthews, K. (2003) Are Bt Crops Safe? Nature Biotechnology, 21, 1003-1009. https://doi.org/10.1038/nbt0903-1003

[102] Rose, R., Dively, G.P. and Pettis, J. (2007) Effects of Bt Corn Pollen on Honey Bees: 
Emphasis on Protocol Development. Apidologie, 38, 368-377. https://doi.org/10.1051/apido:2007022

[103] Lang, S. (2006) Seven-Year Glitch: Cornell Warns That Chinese GM Cotton Farmers Are Losing Money Due to "Secondary” Pests. Cornell University, Ithaca, NY. http://www.news.cornell.edu/stories/2006/07/bt-cotton-china-fails-reap-profit-after -seven-years

[104] Wang, Z., Lin, H., Huang, J., Hu, R., Rozelle, S. and Pray, C. (2009) Bt Cotton in China: Are Secondary Insect Infestations Offsetting the Benefits in Farmer Fields? Agricultural Sciences in China, 8, 83-90. https://doi.org/10.1016/S1671-2927(09)60012-2

[105] Carrington, D. (2012) GM Crops Good for Environment, Study Finds. The Guardian.

[106] Lu, Y., Wu, K., Jiang, Y., Guo, Y. and Desneux, N. (2012) Widespread Adoption of Bt Cotton and Insecticide Decrease Promote Biocontrol Services. Nature, 487, 362-365. https://doi.org/10.1038/nature11153

[107] Kathage, J. and Qaim, M. (2012) Economic Impacts and Impact Dynamics of Bt (Bacillus thuringiensis) Cotton in India. Proceedings of the National Academy of Sciences of the United States of America, 109, 11652-11656. https://doi.org/10.1073/pnas.1203647109

[108] https://cottonaustralia.com.au/

[109] Bourzac, K. (2006) Edible Cotton. MIT Technology Review.

[110] Kalbande, B.B. and Patil, A.S. (2016) Plant Tissue Culture Independent Agrobacterium tumefaciens Mediated In-Planta Transformation Strategy for Upland Cotton (Gossypium hirsutum). Journal of Genetic Engineering and Biotechnology, 14, 9-18. https://doi.org/10.1016/j.jgeb.2016.05.003

[111] Herrera-Estrella, L., De Block, M., Messens, E., Hernalsteens, J.P., Van Montagu, M. and Schell, J. (1983) Chimeric Genes as Dominant Selectable Markers in Plant Cells. The EMBO Journal, 2, 987-995. https://doi.org/10.1002/j.1460-2075.1983.tb01532.x

[112] Horsch, R., Fry, J., Hoffman, N., Eichholtz, D., Rogers, S.A. and Fraley, R. (1985) A Simple and General Method for Transferring Genes into Plants. Science, 227, 1229-1231. https://doi.org/10.1126/science.227.4691.1229

[113] Zhang, Y., Zhang, D., Zhong, Y., Chang, X., Hu, M. and Cheng, C. (2017) A Simple and Efficient in Planta Transformation Method for Pommelo (Citrus maxima) Using Agrobacterium tumefaciens. Scientia Horticulturae, 214, 174-179. https://doi.org/10.1016/j.scienta.2016.11.033

[114] Firoozabady, E., DeBoer, D.L., Merlo, D.J., Halk, E.L., Amerson, L.N., Rashka, K.E. and Murray, E.E. (1987) Transformation of Cotton (Gossypium hirsutum L.) by Agrobacterium tumefaciens and Regeneration of Transgenic Plants. Plant Molecular Biology, 10, 105-116. https://doi.org/10.1007/BF00016148

[115] Chlan, C.A., Lin, J., Cary, J.W. and Cleveland, T.E. (1995) A Procedure for Biolistic Transformation and Regeneration of Transgenic Cotton from Meristematic Tissue. Plant Molecular Biology Reporter, 13, 31-37. https://doi.org/10.1007/BF02668391

[116] Morre, J.L., Permingeat, H.R., Romagnoli, M.V., Heisterborg, C.M. and Vallejos, R.H. (1998) Multiple Shoot Induction and Plant Regeneration from Embryonic Axes of Cotton. Plant Cell, Tissue and Organ Culture, 54, Article No. 131. https://doi.org/10.1023/A:1006170529397

[117] Mishra R., Wang, H.Y., Yadav, N.Y. and Wilkins, T.A. (2003) Development of a Highly Regenerable Elite Acala Cotton (Gossypium hirsutum cv. Maxxa) -A Step 
towards Genotype-Independent Regeneration. Plant Cell, Tissue and Organ Culture, 73, 21-35. https://doi.org/10.1023/A:1022666822274

[118] Ali, M.R., Husnain, T., Hussain, S.S., Mahmood, N. and Riazuddin, S. (2004) Multiple Shoot Regeneration Response of Recalcitrant Cotton (Gossypium hirsutum L.) Cultivar CIM-443. Pakistan Journal of Biological Sciences, 7, 1371-1375. https://doi.org/10.3923/pjbs.2004.1371.1375

[119] Wilkins, T.A., Mishra, R. and Trolinder, N.L. (2004) Agrobacterium-Mediated Transformation and Regeneration of Cotton. Journal of Food, Agriculture \& Environment, 2, 179-187.

[120] Zhu, S.W., Gao, P., Sun, J.S., Wang, H.H., Luo, X.M., Jiao, M.Y., Wang, Z.Y. and Xia, G.X. (2006) Genetic Transformation of Green-Colored Cotton. In Vitro Cellular \& Developmental Biology, 42, 439-444. https://doi.org/10.1079/IVP2006777

[121] Ikram-Ul-Haq (2004) Agrobacterium-Mediated Transformation of Cotton (Gossypium hirsutum L.) via Vacuum Infiltration. Plant Molecular Biology Reporter, 22, 279-288. https://doi.org/10.1007/BF02773138

[122] Cao, J.-L., Zhang, X.-L., Jin, S.-X., Yang, X.-Y., Zhu, H.-G. and Fu, L.-L. (2008) An Efficient Culture System for Synchronization Control of Somatic Embryogenesis in Cotton (Gossypium hirsutum L.). Acta Agronomica Sinica, 34, 224-231. https://doi.org/10.3724/SP.J.1006.2008.00224

[123] Keshamma, E., Rohini, S., Rao, K.S., Madhusudhan, B. and Kumar, M.U. (2008) Molecular Biology and Physiology Tissue Culture-Independent in Planta Transformation Strategy: An Agrobacterium tumefaciens-Mediated Gene Transfer Method to Overcome Recalcitrance in Cotton (Gossypium hirsutum L.). Journal of Cotton Science, 12, 264-272.

[124] Rech, E.L., Vianna, G.R. and Aragao, F.J. (2008) High-Efficiency Transformation by Biolistics of Soybean, Common Bean and Cotton Transgenic Plants. Nature Protocols, 3, 410-418. https://doi.org/10.1038/nprot.2008.9

[125] Chen, T.-Z., Wu, S.J., Zhao, J., Guo, W.Z. and Zhang, T.-Z. (2010) Pistil Drip Following Pollination: A Simple in Planta Agrobacterium-Mediated Transformation in cotton. Biotechnology Letters, 32, 547-555. https://doi.org/10.1007/s10529-009-0179-y

[126] Amudha, J., Balasubramani, G., Malathi, V.G., Monga, D. and Kranthi, K.R. (2011) Cotton Leaf Curl Virus Resistance Transgenics with Antisense Coat Protein Gene (AV1). Current Science, 101, 300-307.

[127] Sohrab, S.S., Azhar, E.I., Kamal, M.A., Bhattacharya, P.S. and Rana, D. (2014) Genetic Variability of Cotton Leaf Curl Betasatellite in Northern India. Saudi Journal of Biological Sciences, 21, 626-631. https://doi.org/10.1016/j.sjbs.2014.11.006

[128] Bajwa, K.S., Shahid, A.A., Rao, A.Q., Bashir, A., Aftab, A. and Hussain, T. (2015) Stable Transformation and Expression of GhEXPA8 Fiber Expansion Gene to Improve Fiber Length and Micronaire Value in Cotton. Frontiers in Plant Science, 6, 838. https://doi.org/10.3389/fpls.2015.00838

[129] Huang, G., Dong, Y. and Sun, J. (1999) Introduction of Exogenous DNA into Cotton via the Pollen-Tube Pathway with GFP as a Reporter. Chinese Science Bulletin, 44, Article No. 698. https://doi.org/10.1007/BF02909705

[130] Ali, A., Bang, S.W., Chung, S.M. and Staub, J.E. (2015) Plant Transformation via Pollen Tube-Mediated Gene Transfer. Plant Molecular Biology Reporter, 33, 742-747. https://doi.org/10.1007/s11105-014-0839-5

[131] Zhou, G.Y., Weng, J., Zeng, Y., Huang, J., Qian, S. and Liu, G. (1983) Introduction of Exogenous DNA into Cotton Embryos. Methods in Enzymology, 101, 433-481. 
https://doi.org/10.1016/0076-6879(83)01032-0

[132] Luo, Z. and Wu, R. (1989) A Simple Method for the Transformation of Rice via the Pollen-Tube Pathway. Plant Molecular Biology Reporter, 7, 69-77.

https://doi.org/10.1007/BF02669248

[133] Yang, L., Cui, G., Wang, Y., Hao, Y., Du, J., Zhang, H., Wang, C., Zhang, H., Wu, S. and Sun, Y. (2017) Expression of Foreign Genes Demonstrates the Effectiveness of Pollen-Mediated Transformation in Zea mays. Frontiers in Plant Science, 8, 383. https://doi.org/10.3389/fpls.2017.00383

[134] Hu, C. and Wang, L. (1999) In Planta Soybean Transformation Technologies Developed in China: Procedure, Confirmation and Field Performance. In Vitro Cellular \& Developmental Biology, 35, 417-420.

https://doi.org/10.1007/s11627-999-0058-1 